Tarih Kültür ve Sanat Araştırmaları Dergisi (ISSN: 2147-0626)

\title{
DOI: 10.7596/taksad.v3i1.323
}

\section{Ehl-i Sünnet Açısından Bilgi ve Değeri}

\section{İsmail YÜCEDAĞ $\breve{G}^{1}$}

\section{$\ddot{O} z$}

Kelâm ilmînin amacı, dinî inançları kesin deliller kullanarak ispat etmektir. Bu nedenle kelâmcılar Kur'an'ı ve iki kısma ayırdıkları Sünnet'in ilk kısmında yer alan mütevâtir haberleri esas almışlardır. Kelâm ilminde üç bilgi edinme yolu olduğu kabul edilmiştir. Bunlar, beş duyu, akıl ve haber-i sâdık’tır. Bilgi edinme yollarından ilk ikisini oluşturan beş duyu ve akıl ile elde edilen bilgiler ile Sünnet'in ilk kısmında yer alan mütevâtir haberin değeri konusunda İslâm âlimleri arasında bir ihtilâf söz konusu değildir. Hicretin II. asrından itibaren, sünnetin ikinci kısmını oluşturan haber-i vahid'in değeri ve itikâdî konularda delil teşkil edip etmeyeceği konusunda âlimler tarihsel süreç içinde birbirinden farklı görüşler ortaya koymuşlardır. Böylelikle problem günümüze kadar devam etmiştir. Konu hakkında fikir yürüten âlimler, Kelâmcılar ve Selefiyye olmak üzere iki ana gruba ayrılmışlardır. Bu çalışmanın amacı, haber-i vâhid hakkındaki fikir ayrılıklarının nedenlerini, kelâmcılar tarafından bilgi edinme yollarından biri olarak kabul edilen haber-i sâdıkı dikkate alarak araştırmaktır.

Anahtar kelimeler: Ehl-i Sünnet, Haber-i Sâdık, Bilginin Değeri, Haber-i Vâhid, Kelâmcılar, Selefiyye.

\footnotetext{
${ }^{1}$ Karabük Üniversitesi Edebiyat Fakültesi Felsefe Bölümü Öğretim Üyesi.
} 


\title{
Knowledge and its Value in Terms of the Ahl As-Sunnah
}

\begin{abstract}
The purpose of the Kalam science is to prove the religious beliefs by using definitive evidences. For this reason, the Kalam scholars are inclined to Koran and the mutawatir reports which are included in the first part of Ahl As-Sunnah divided into two parts. In the Kalam science, it has been accepted that there are three ways of attaining knowledge. These are the five senses, intelligence, and precise reports. It is not the case that Islamic scholars have a disagreement on not only knowledges obtained through the five senses and intelligence but the value of mutawatir reports included in the first part of Ahl As-Sunnah. As of the second century of Hegira, the scholars have put forward different opinions about whether the value of imprecise reports will constitute an evidence in matters of faith in the historical process or not. Thus, the problem has continued to the present day. The scholars who speculate about the issue have been divided into two main groups as Kalam scholars and Salafism. The purpose of this study is to research the reasons for the disagreements on imprecise reports by taking precise reports into account, which has been accepted by Kalam scholars as one of the ways of attaining knowledge.
\end{abstract}

Keywords: Ahl As-Sunnah, Precise news, The Value of Knowledge, Imprecise news, Kalam Scholars, Salafism.

\section{Giriş}

Kelâm ilminde, bilgi kelimesini karşılamak için ilim kelimesi kullanılmıştır. İlim kelimesi, arapça 'a.l.m.' kökünden türemiş olup, bilmek, anlamak, kavramak, haber vermek, zannetmek, bir şeyi gerçeğe uygun olarak bilmek anlamlarına gelen bir mastar isimdir².

Bilgi kelimesi 1stılahta, gerçeğe uygun kesin bilgi ${ }^{3}$, eşyayı olduğu şekilde bilmek ${ }^{4}$, kişinin bilgi sahibi olmasını gerektiren şey ${ }^{5}$, her hangi bir konuda fikir yürütme kabiliyeti kazandıran bir güç ${ }^{6}$ olarak da tarif edilmiştir.

Fahreddin er-Râzî(v.606/1210), bilgi konusunu işlerken, kelâmcıların ve İslâm filozoflarının bilgi tariflerini ele alır ve bu tariflerin her birinin ayrı ayrı eksikliklerinin

\footnotetext{
${ }^{2}$ İbn Manzûr, Lisânu'l-Arab, 'a.l.m.' md.; el-Isfahânî, el-Müfredât fi Garîbi'1-Kur'ân, s.503

${ }^{3}$ el-Cürcânî, et-Ta'rîfât, 'el-İlm' md.

${ }^{4}$ el-Bâkıllânî, Kitâbu't- Temhîd, s.6

${ }^{5}$ el-Cüveynî, el-İrşâd ilâ Kavâtıı' 1-Edille fì Usûli'l-í'tikâd, s.12 (Bu tarif Eş'arî’ye aittir.)

${ }^{6}$ et-Tehânevî, Keşşâfu Istılâhâti'l-Funûn, 'el-İlm' md.
} 
bulunduğunu anlatır. Daha sonra, bilgi kelimesi ile eş anlamlı olduğunu düşündüğü otuz lâfzı ayrı ayrı açıklar ${ }^{7}$.

Mutlak anlamda bilgi, kadîm ve hâdis olmak üzere iki kısma ayrılır:

1-Kadîm Bilgi: Allah'ın zatına mahsus olan bilgilerdir. Bu bilgiler yaratılmışların bilgisine benzemez.

2-Hâdis Bilgi: Yaratılmışlara ait olan bilgilerdir. Zarûrî ve iktisâbî olmak üzere iki kısma ayrılmıştır.

a) Zarûrî Bilgi: Allah'ın 'bilen'in nefsinde, kendi irade ve gayreti olmaksızın meydana getirdiği bilgidir. Kişinin kendi varlığını, açlık, susuzluk, haz, elem gibi değişik hallerini hissedip kesin şekilde bilmesi gibi. Bu çeşit bilgiler bütün canlı yaratıklarda mevcuttur. Zarûrî bilgi de sonradan bazı kısımlara ayrılmıştır. Bu sınıflandırma, daha çok kelâmcıların felsefe ile olan ilişkilerinin gelişmesinden sonra yapılmış ve bu sınıflandırmada mantık ilminin etkisinde kalınmıştır:

(1) Bedîhiyyât (Evveliyât): Aklın hiçbir delile başvurmaksızın, kendisine yönelmesiyle meydana gelen bilgilerdir. 'Bir bütün, kendi parçalarından büyüktür', hükmünde olduğu gibi.

(2) Fitriyyât: Aklın basit bir kıyas ile vardığı hükümdür. Akıl, 'dört sayısı çifttir', önermesinde, dört ve çift terimlerini düşünürken, dört ikiye bölünür, ikiye bölünen sayılar çifttir şeklinde yaptığı gizli bir kıyas sonucu hükme varır.

(3) Müşâhedât: Dış duyular vasıtasıyla elde edilen bilgilerdir. 'Güneş 1şık saçar', 'ateş yakar', gibi. Eğer bilgi, kişinin açlık veya susuzluk hissetmesi gibi iç duyular vasıtasıyla elde edilirse buna da 'vicdâniyyât' adı verilir.

(4) Hadsiyyât: Hads, zihnin anî kavramasıdır. Öncüllerden neticelere varma veya öncül ve neticelerin aynı anda zihinde mevcut olmasıyla elde edilen bilgilerdir. Bulutun çıkmasının yağmur yağacağına delâlet etmesi gibi.

(5) Mücerrebât: Tekrar edilen deneyler sonunda elde edilen bilgilerdir. Sert bir cisimle dövmek ağrı vericidir, gibi.

(6) Mütevâtirât: Akıl için imkânsız görünmeyen, defalarca işitilen ve çoğunluğun tasdik etmesiyle edinilen bilgilerdir. Görülmeyen bir şehrin varlığını sürekli işitme sonucu kabul etmek gibi ${ }^{8}$.

b) Nazarî(Kuramsal)-îstidlâlî bilgi: Bilinmeyeni elde etmek için, kulun sebeplere tevessül etmesi sonucunda Allah'ın, kulun kendi gayret ve iradesi yoluyla onda meydana

\footnotetext{
${ }^{7}$ Fahreddîn er-Râzî, Mefâtîhu'l-Gayb, II/175 vd.

${ }^{8}$ el-Bâkıllânî Kitâbu't- Temhîd, s. 8; es-Sâbûnî, el-Bidâye fî Usûli'd-Dîn, s,17 vd; el-Harpûtî, Tenkîhu'1-Kelâm fî Akâid-i Ehli’l-İslâm, s.12 vd; Bekir Topaloğlu, Kelâm İlmi Giriş, s.71; Necati Öner, Klâsik Mantık, s. 184 vd.
} 
getirdiği bilgidir. Burada bilinmeyenin elde edilmesi için düşünce ile ilgili bir işleme ihtiyaç vardır ki bu da delil kullanmak suretiyle gerçekleşir?'

\section{I-Kelâm İlminde Bilgi Edinme Yolları}

Kelâm ilminde bilgi edinme yolları üç olarak kabul edilmiştir. Bunlar, beş duyu, akıl ve haber-i sâdıktır.

Teftâzânî(v.793/1390)'ye göre, kelâm âlimlerinin bilgi edinme yollarını üç olarak kabul etmelerinin nedeni, kendi maksatlarına uygun olmasından dolayıdır. Çünkü kelâmcıların amacı, bilgi edinme yollarının türlerini saymak ve bunlarla ilgili hükümleri detaylarına varıncaya kadar incelemek değildir. Onların asıl amacı, iman ve inanca taalluk eden konuları sistematik bir şekilde açıklamaktır. Bundan dolayı zaruri bilginin kısımlarını oluşturan hadsler, tecrübeler, bedihiyyât, nazariyyât ayrı ayrı bilgi vasıtası olarak incelenmemiş, hepsinin mercii akıl olduğundan, akıl bütünlüğünde incelenmiştir ${ }^{10 "}$

Ayrıca nübüvvet sıfatını taşımayan kişilerde meydana gelebilecek ilham, ancak kendileri için ilim sebebi sayılmış, fakat peygamberler bundan istisna tutulmuştur ${ }^{11}$.

Aslında kelâmcılar, bilgi edinmede, akıl, beş duyu ve haber-i sâdıkı müessir sebep olarak kabul etmezler. Bundan dolayı onlar akla, zahirî sebep demişlerdir. Duyular ve haberler ise idrakin meydana gelmesinde vasita olma görevini üstlenirler. Ancak, her türlü bilginin meydana gelmesinin müessir sebebi Allah'tır. İdrak etmeyi meydana getiren asıl sebep ise Allah'ın bizde idrak ile aynı anda tabiat kanunları çerçevesinde yarattı̆̆ bilginin yaratılmaması halinde idrak söz konusu olamaz ${ }^{12}$.

\section{A- Beş Duyu (Havass-ı Selîme)}

a-Tarifi

Havass kelimesi, duyu kuvveti, duyu gücü anlamına gelen hasse kelimesinin çoğuludur $^{13}$. Beş duyu, işitme, görme, koklama, tatma ve dokunma'dan ibarettir. İdraklerin bir kısmının, duyu organlarından birini kullanmanın hemen ardından meydana gelmesinden dolayı, duyu organları bilgi edinme yollarından biri olarak kabul edilmiştir ${ }^{14}$. Ancak bilginin idrak edilmesinde beş duyu sadece vasıta olma görevini yerine getirir. Yani bilgiyi idrak eden beyindir. Duyuların görevi kendilerine ulaşan şeyi beyne iletmektir. Yalnız, duyulardan her biri vasıtasıyla ancak kendi sahasına ait olan şeylerin idrak olunabileceğini ${ }^{15}$ belirtmek

\footnotetext{
${ }^{9}$ el-Bâkıllânî, Kitâbu't- Temhîd, s.8; es-Sâbûnî, el-Bidâye fî̀ Usûli'd-Dîn, s.17; Bekir Topaloğlu, Kelâm İlmi Giriş, s. 72

${ }^{10}$ et-Teftâzânî, Şerhu' 1-Akâid, s.29 vd.

${ }^{11}$ Ömer Nasuhi Bilmen, Muvazzah Illm-i Kelâm, s.13

${ }^{12}$ et-Teftâzânî, a.g.e, s.29

${ }^{13}$ İzmirli İsmail Hakkı, Yeni İlm-i Kelâm, s.33

${ }^{14}$ et-Teftâzânî, a.g.e, s.29 vd.

${ }^{15}$ es-Sâbûnî, el-Bidâye fî Usûli'd-Dîn, s,17; es-Sâbûnî, el-Kifâye fi'l-Hidâye, vr.4b
} 
gerekmektedir. Ancak duyular ile bilgi elde edilebilmesi için duyuların selîm yani arızasız ve sağlıklı olması gerekmektedir. Aksi halde görme yeteneğini veya işitme özelliğini kaybetmiş bir duyu organı ile bilgi edinilemeyeceği son derece açıktır.

b-Değeri

Duyular ile elde edilen bilgilerin kesin bilgi olduğu kabul edilmiştir ${ }^{16}$. Bu bilgiler delil ve istidlâle muhtaç değildir. Bundan dolayı kendilerinde şüphe ve tereddüt bulunmaz ${ }^{17}$.

\section{B. Akıl}

a-Tarifi

Akıl kelimesi, 'a.k.l.' kökünden türemiş olup, anlamak ve idrak etmek, yüksek bir dağa çıkmak, bir yere sığınmak, kan bedeli, diyet vb. anlamlara gelen bir mastar isimdir ${ }^{18}$.

Akıl kelimesi 1stılahta, bilinmeyen şeyleri vasıtalar ve duyu organları ile idrak eden soyut bir cevher ${ }^{19}$, insanı, diğer canlılardan ayıran bir güç ${ }^{20}$, insanda mevcut olan, özel bir kabiliyet ile elde edilen ilim ve ilmi kabul için hazırlanmış bir kuvvet ${ }^{21}$, insanın, sayesinde

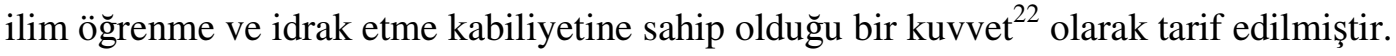

Gazzâlî(v.505/1111) ye göre akıl kelimesinin üzerinde birleşilen bir tarifinin yapılamayışının nedeni, aklın birçok manalar için ortak bir isim olmasından dolayıdır ${ }^{23}$.

b-İtikadi konularda aklın rolü

Akıl ilâhî tekliflerin vaki olması için kaçınılmaz bir şarttır. Akıldan yoksun olanlar, ilâhî kanunlarca sorumlu tutulmamıştır. Akıl, hayır ile şerri, güzel ile çirkini idrak eder ve ayırır. Fakat dinin esaslarını teşkil eden ve kelâm ilminde mesâil diye adlandırılan ana prensipleri ortaya koyamaz ${ }^{24}$.

İtikâdî konulardan ulûhiyet ve nübüvvet ile ilgili problemlerde, akıl bir takım izah ve ispatlar yapabilir. Ancak sem'iyyât konularında akıl, nakle dayanma durumundadır. Çünkü akıl her şeyi bulamaz. Aklın bulamadığı şeyleri din tebliğ eder, akıl da benimser ${ }^{25}$.

Aslında dinin tebliğ ettiği konular aklen mümkün olan şeylerdir. Sem'iyyât konuları da bunlara dâhildir. Bunlar hakkında delil varit olduğunda ve aklen mümkün görüldüğünde ona inanmak artık vacip olur ${ }^{26}$.

\footnotetext{
${ }^{16}$ İzmirli İsmail Hakkı, Yeni İlm-i Kelâm, s.34

${ }^{17}$ el-Bâkıllânî, Kitâbu't- Temhîd, s. 9

${ }^{18}$ İbn Manzûr, Lisânu'l-Arab, 'a.k.l.' md.;

${ }^{19}$ el-Cürcânî, et-Ta'rîfât, 'el-akl' md.

${ }^{20}$ İbn Manzûr, a.g.e, a.md.

${ }^{21}$ el-Isfahânî. el-Müfredât fi Garîbi'l-Kur'ân, s. 511

${ }^{22}$ et-Teftâzânî, Şerhu'l-Akâid, s.41

${ }^{23}$ el-Gazzâlî, Mi'yâru'l-ìlm, s.80

${ }^{24}$ el-Cüveynî, eş-Şâmil fì Usûli'd-Dîn, s.115

${ }^{25}$ İzmirli İsmail Hakkı, Yeni İlm-i Kelâm, s.31
} 
$\mathrm{Bu}$ durumda akıl nakli tasdik eden, naklin getirdiği esas ve hükümlerin hikmetlerini anlayabilen bir vasıta olduğundan, vahyin ışığında aynı zamanda hatadan da korunmuş olmaktadır ${ }^{27}$.

c-Akıl yoluyla elde edilen bilgiler ve değeri

Akıl yolu ile meydana gelen bilgi iki kısma ayrılır:

a) Zarurî bilgi: Düşünmeden ilk bakışta meydana gelen bilgidir. Bir bütünün kendi parçalarından büyük olduğunu bilmek gibi.

b) İstidlâlî bilgi: Düşünme sonucu meydana gelen bilgidir ki şu üç şekilden biri ile olur:

(1) Ta'lîl (Dedüksiyon): Bütünden parçaya, diğer bir ifade ile müessirden esere geçiş metodudur;

" Bütün cisimler tartılabilir,

Taş, toprak, su .... birer cisimdir,

O halde bunlar da tartılabilir."

(2) İstikra' (Endüksiyon): Parçadan bütüne veya eserden müessire geçiş metodudur:

"Taş, toprak, su.... tartılabilir,

Taş, toprak, su.... birer cisimdir,

O halde bütün cisimler tartılabilir."

(3) Temsil (Analoji): İki şey arasındaki benzerliğe dayanıp, birisi hakkında verilen bir hükmü diğeri hakkında da vermektir:

"Şarap haramdır, çünkü sarhoşluk vericidir,

O halde sarhoşluk veren rakı da haramdır ${ }^{28}$."

\section{Haber-i Sâdık}

a-Tarifi

Haber kelimesi, "h.b.r." kökünden türemiş olup, lâzım ve müteaddî kullanılışlarına göre bilmek, iç yüzünü bildiği şeyi duyurmak, sütü bol deve, sedir ağacı, su yatağı, sedir ağacı yetişen yer ve etrafında biten otlar anlamlarına gelmektedir ${ }^{29}$.

\footnotetext{
${ }^{26}$ es-Sâbûnî, el-Kifâye fi'l-Hidâye, vr.90b-91a.

${ }^{27}$ Bekir Topaloğlu, Kelâm İlmi Giriş, s.84

28 en-Nesefî, Tebstretu'l-Edille, vr.6b; es-Sâbûnî, el-Kifâye fi'l-Hidâye, vr.4b; et-Teftâzânî, Şerhu'l-Akâid, s.43vd; İzmirli İsmail Hakkı, Yeni İlm-i Kelâm, s.35; Bekir Topaloğlu, Kelâm İlmi Giriş, s.79; Necati Öner, Klasik Mantık, s. 172 vd.
} 
Haber kelimesi 1stılahta, haber yönünden bilinebilen şeyleri malumat yönünden bilmek $^{30}$, doğru ve yanlışa ihtimali olan söz ${ }^{31}$, haber verenden nakledilen gerçeğe uygun söz ${ }^{32}$...vvb. şekillerde tarif edilmiştir.

Haber-i sâdık, gerçeğe uygun olan haber demektir ${ }^{33}$. Ancak bir habere, haber-i sâdık denilebilmesi için o haberin, geçmişte de, şu anda da gerçeğe uygun olması gerekmektedir ${ }^{34}$.

Dinî bilgilerin büyük bir bölümünün doğru haberler vasıtasıyla öğrenildiğini gören kelâmcılar, haber-i sâdık’ı ayrı bir bilgi elde etme vasıtası olarak kabul etmişlerdir ${ }^{35}$.

b-Çeşitleri

Haber-i sâdık iki kısma ayrılır:

a) Haber-i Mütevâtir: Yalan söyleme konusunda anlaşabilecekleri aklen tasavvur olunamayan, kalabalık bir insan topluluğundan aynı konuda işitilen haberdir ${ }^{36}$.

b) Haber-i Resûl: Mucize ile teyit olunan resulün verdiği haberdir ${ }^{37}$. Çünkü peygamberlik, ancak mucize göstermekle sabit olur ${ }^{38}$. Peygamber olduğunu iddia eden şahsın, bu iddiasını tasdik etmek için, Allah'ın o kimse vasıtasıyla meydana getirdiği ve insanlar tarafından benzerinin yapılamadığı şeylere mucize adi verilir ${ }^{39}$.

Usulcülere göre haber-i resûl üç kısma ayrılır:

a. Haber-i mütevâtir

b. Haber-i meşhur

c. Haber-i vahid ${ }^{40}$

Haber-i resûl, mucize ile teyîd olunduğundan, kendisinde yalan ihtimali bulunmaz. Haber-i resûl ile elde edilen bilgi, peygamber olduğunu iddia eden şahsın mucize göstermesinden önce istîdiâlî bir bilgidir. Fakat mucize göstermesinden sonra haber-i resûl,

\footnotetext{
${ }^{29}$ İbn Manzûr, Lisânu'l-Arab, 'h.b.r.' md.;

${ }^{30}$ el-Isfahânî, el-Müfredât fi Garîbi'1-Kur'ân, s.203vd.

${ }^{31}$ el-Cüveynî, el-İrşâd ilâ Kavâtıı'1-Edille fî Usûli'l-İ'tikâd, s.411

32 İbn Manzûr, Lisânu'l-Arab, 'h.b.r.' md

33 et-Teftâzânî, Şerhu'l-Akâid, s.33

${ }^{34}$ Ali Arslan Aydın, İslâm İnançları ve Felsefesi, s.95

35 et-Teftâzânî, Şerhu'l-Akâid, s.30

${ }^{36}$ İzmirli İsmail Hakkı, Yeni İlm-i Kelâm, s.34

${ }^{37}$ es-Sâbûnî, el-Bidâye fî̀ Usûli'd-Dîn, s.17

${ }^{38}$ İzmirli İsmail Hakkı, a.g.e, s.34

${ }^{39}$ Ali Arslan Aydın, İslâm Inançları ve Felsefesi, s.96

40 et-Tehânevî, Keşşâfu Istılâhâti'l-Funûn, 'el-haber' md.
} 
mahsûsat, bedihiyyât, müşahedât, mütevâtirât gibi zarûrî ilim ifade eder ${ }^{41}$. Bu zarûret, zıddına ihtimali olmamak, şüpheye düşen kimsenin ileri sürdüğu itirazlarla yok olup ortadan kalkmaya ihtimali olmamak anlamına gelir ${ }^{42}$. Kelâm âlimlerinin, haber-i resûlü, doğru ve gerçek bilgiye götüren bilgi yollarından biri olarak kabul etmelerinin bir başka nedeni de, bu çeşit haberlerin hatadan masun olan vahye, yani ilâhî bir esasa dayanmasından ${ }^{43}$ dolayıdır.

Haber-i sâdık konusu işlenirken, her ne kadar usulcülere göre haber-i resûlün üç kısma ayrıldığı belirtilmiş ise de, kelâm âlimleri haber-i meşhûrun, genelde haber-i vâhid sınırları içinde yer almasından dolayı, haber-i resûlü, mütevâtir ve âhâd haberler olmak üzere iki kısma ayırırlar ${ }^{44}$.

Haber-i sâdıkın ikinci kısmında yer alan haber-i resûl, mütevâtir ve âhâd haberlerden meydana geldiğinden, haber-i sâdıkın birinci kısmında da haber-i mütevâtirin yer alması ve özellikle haber-i resûlün ilk kısmıyla müştereklik arz etmesinden dolayı, haber-i sâdıkın, haber-i mütevâtir ve haber-i vâhid olmak üzere iki kısımda incelenmesi uygun görülmüştür.

\section{II- Ehl-i Sünnet'e göre Haber-i Mütevâtir ve Haber-i Vâhid}

\section{A- Haber-i Mütevâtir}

a-Tarifi

Yalan söyleme hususunda ittifak edebilecekleri tasavvur olunamayan farkl1 kimselerden aynı konuda işitilen haberdir ${ }^{45}$. Suyutî(v.911 h.), Tebrîbu'r-Râvî Şerhu Takribi'nNevevî adlı eserinde mütevâtir haberi, başlangıcından sonuna kadar doğruluklarında zarurî ilim hâsıl olan kişilerin naklettiği haber, diye tarif ettikten sonra bu tarifin hadisçilere ait olduğunu belirtir ${ }^{46}$.

Mütevâtir haberin tarifinde geçen yalan üzerine ittifaklarını aklın kabul etmeyeceği topluluğun sayısı konusunda usulcüler ihtilaf halindedirler. Bir kısmı bu topluluğu, 'ehl-i meşrık ve mağrib' olarak vasıflandırmış ve şarktakilerle garptakilerin ittifak halindeki rivayetlerinin tevatür derecesinde olduğunu söylemişlerdir. Bir kısmı, 'bizim sayamayacağımız adetteki bir kalabalığın rivayeti’ olarak tarif etmiştir. Bundan sonraki görüşler ise bazı sınırlı rakamlara dayanmaktadır. Bunlara göre, tevatür ancak üç yüz on kişinin rivayetiyle sabit olur ki bu rakam, Bedir savaşına katılanların sayısını gösterir. İleri sürülen

\footnotetext{
${ }^{41}$ İzmirli İsmail Hakkı, Yeni İlm-i Kelâm, s.34

${ }^{42}$ en-Nesefî̀, Tebsiretu' 1-Edille, vr. 6a; İzmirli, Yeni İlm-i Kelâm, s. 34

${ }^{43}$ Ali Arslan Aydın, İslâm İnançları ve Felsefesi, s.96

${ }^{44}$ el-Matürîdi, Kitâbu 't-Tevhîd, s.9; el-Cüveynî, el-İrşâd ilâ Kavâtu' '1-Edille fî Usûli'l'-ì'tikâd, s.416; el-Âmidî, el-ïhkâm fì Usûli'1-Ahkâm, II/14

${ }^{45}$ es-Sâbûnî, el-Kifâye fi'l-Hidâye, vr.4b;

${ }^{46}$ es-Suyûtî, Tebrîbu'r-Râvî, Şerhu Takribi'n-Nevevî, s.371
} 
diğer rakamlar ise, iki, üç, dört, beş, on iki, yirmi, kırk, elli, yetmiştir ${ }^{47}$. Bütün bu rakamlar Kur'an-1 Kerim'de geçen bazı ayetlere dayandırılmak istenmiştir.

Subhî es-Salih, Ulûmu'l-Hadîs'inde, 'bütün bu istidlaller, isterse Kur'an-1 Kerim'den istinbat edilmiş olsun açık ve net değildir. Zira bütün bu ayet-i kerimeler, orada zikredilen özel bir konu ile ilgilidir' diyerek bu görüşleri reddeder ${ }^{48}$.

b-Bilgi ifade etmesinin şartları

Mütevâtir haberin tarifinde geçen, yalan üzerinde ittifakları kabul edilemeyen bir topluluğun, yalan söyleyip söyleyemeyeceği problemine usulcüler değişik açılardan bakıp çözüm bulmaya çalışmışlar ve böyle bir topluluğun yalan üzerine ittifak edemeyeceklerinde birleşmişlerdir.

Bakıllânî(v.403/1013), bu topluluğun yalan üzerinde birleşmelerinin mümkün olamayacağını şu cümlelerle izah eder:

"Mütevâtir haberi nakleden kişilerin yalan üzerinde birleşmeleri düşünülemez. Bu sayıdaki kişilerin kendi aralarında anlaşıp bazı şeyleri gizleyeceklerini veya yalan üzerinde birleşeceklerini kabul etmek mümkün değildir. Çünkü böyle bir şeye teşebbüs edilirse aralarında anlaşmazlık çıkabilir. Ancak bir veya iki kişi arasında böyle bir anlaşma söz konusu olabilir. Fakat topluluğu meydana getiren fertlerin tek tek yalan söylemelerinin mümkün olmasından dolayı, topluluğun yalan üzerinde birleşmesi mümkün olsaydı, ferdin kusurlarını topluluğun bütününde de görmek gerekirdi, hâlbuki bu muhaldirr ${ }^{49 " . ~ B u}$ açıklamasından sonra da, mütevâtir haberde mevcut olması gereken şartları anlatır. Bakıllânî̉ nin bu konudaki şartlarını üç madde halinde toplamak mümkündür:

a) Mütevâtir haberi nakledenler, naklettikleri haberi nazarî bilgi ile değil, zarurî bilgi veya beş duyu ile bilmelidirler.

b) Nakledilen haber Müslümanların aynı konudaki haberlerine ters düşmemelidir.

c) Haberi rivayet edenlerin sayısı, her ne kadar haberi alanın takdirine bırakılmışsa da en az dört kişi olmalıdır ${ }^{50}$.

İmâmu' 1-Haremeyn Cüveynî(v.478/1085)'nin bu konudaki düşüncelerinin daha farklı olduğu görülmektedir. Cüveynî nin şartları dört madde halinde toplanabilir:

a) Mütevâtir haberi nakledenler, rivayet ettikleri haberi zarurî bir bilgi ile bilmelidirler.

\footnotetext{
${ }^{47}$ İbn Hazm, el-İhkâm fi Usûli'l-Ahkâm, I/94; el-Âmidî, el-İhkâm fî Usûli'1-Ahkâm, II/25vd.

${ }^{48}$ Subhi es-Sâlih, Ulûmu'l-Hadîs, s.147vd.

${ }^{49}$ el-Bakıllanî, Kitâbu't- Temhîd, s.382 vd.

${ }^{50}$ el-Bakıllanî, a.g.e. s.583 vd.
} 
b) Yalan üzerine birleşmeleri mümkün olmayan bir çoğunluk derecesine varmaları gerekir. Cüveynî, bu sayı hakkında açıklamalarda bulunurken, şehadet esnasında istenen dört şahit konusunu örnek gösterir ve en az dört kişinin rivayetini öngörür.

c) Ravîlerin adalet sıfatlarının, tevatür yoluyla ispat edilmesi şart olmadığı gibi, imanlarının bulunması da şart değildir. Çünkü uzak memleketlerde bulunan bir kavimden, tevatür yolu ile krallarının kendilerini öldürmekte olduğu duyulsa, bu haberi verenler tasdik edilir.

d) Haberi rivayet eden ravîlerin aynı milletten olmaları da şart değildir ${ }^{51}$.

Amidî(v.631/1233)'nin el-İhkâm adlı eserindeki mütevâtir haberlere ait şartlar yine dört maddede toplanabilir:

a) Haberi rivayet eden râvîlerin, yalan üzerinde birleşmeleri mümkün olmayan bir çoğunluk derecesine varmaları gerekir.

b) Rivayet ettikleri haberi kendi zanlarında bir haber olarak nakletmemelidirler.

c) Rivayet ettikleri haber, aklî muhakemeye değil, duyu organlarına dayanmış olmalıdir.

d) Nakledilen haberin bütünlüğünde bir çelişki olmamalıdır ${ }^{52}$.

$$
\text { c-Çeşitleri }
$$

Mütevâtir haberler iki kısma ayrılır:

a) Lafzî mütevâtir: Yalan üzerinde birleşmesi mümkün olmayan bir topluluğun, senedin başından sonuna kadar haberin metnini aynı lâfızlarla rivayet ettikleri haberdir. Muhaddislerin rivayetlerinde, mütevâtir yok denecek kadar azdır" . Ancak "Men kezebe aleyye müteammiden......" hadisi lafzî mütevâtir olarak çoğunlukla kabul edilmiştir ${ }^{54}$.

b) Manevî mütevâtir: Yalan üzerinde birleşmesi mümkün olmayan bir topluluğun değişik ifadelerle fakat manada birleştikleri haberlere verilen addır ${ }^{55}$. Manevî mütevâtirlerin inkâr edilemeyecek kadar fazla olduğu kabul edilmiştir. Hz. Peygamber (a.s.)'den rivayet edilen yüze yakın hadiste, onun dua ederken ellerini kaldırdığına dair haber, manevî mütevâtire örnek gösterilebilirr ${ }^{56}$.

\footnotetext{
${ }^{51}$ el-Cüveynî, el-İrşâd ilâ Kavâtul' 1-Edille fî Usûli'l-I'I'tikâd, s.413vd.

${ }^{52}$ el-Âmidî, el-ïhkâm fî Usûli'1-Ahkâm, II/24vd

${ }^{53}$ es-Suyutî, Tebrîbu'r-Râvî, Şerhu Takribi'n-Nevevî, s.371; en-Nevevî, et-Takrîb, s.41

${ }^{54}$ es-Suyutî, a.g.e, s. 374; en-Nevevî, et-Takrîb, s. 41

${ }^{55}$ es-Suyutî, a.g.e, s. 374

${ }^{56}$ Nevevî(v.676/1277), et-Takrîb adlı eserinde, manevî mütevâtir hadisler arasında sayılan, 'Ameller niyetlere göredir' hadisinin mütevâtir olmadığını söyler. Bu düşünceye Suyutî ve Subhi es-Salih de katılmaktadır (enNevevî, et-Takrîb, s. 41; es-Suyutî, a.g.e, s. 374; Subhi es-Sâlih, Ulûmu'l-Hadîs, s.150). Yine, Suyutî (v.911 h.) kendi deyimiyle, daha önce benzerine rastlamadığı türde bir kitap tertip etmiş, el-Ezhâru'1-Mütenâsire fi'l-
} 


\section{d-Akâid sahasındaki mütevâtir haberler}

Kettânî, Nazmu'l-Mütenâsir fi'l-Hadîsi'l-Mütevâtir adlı eserinde, mütevâtir olarak kabul edilen hadisleri toplamış ve lafzî mütevâtir ile manevî mütevâtirleri ayrı ayrı belirtmiştir. Aynı konudaki manevî mütevâtirleri ise bir araya toplayarak sadece konularını zikretmiş ve rivayet eden ravilerin sayı ve isimlerini de nakletmiştir. Kettânî’nin eserinde tespit edilebilen akâid sahasındaki mütevâtir haberler şunlardır:

'Bir kimse Allah'ın birliğine şehadet ederse cennet ona vacip olur' hadisi ${ }^{57}$.

'Lâ ilâhe illallâh deyinceye kadar onlarla savaşmakla emrolundum....' hadisi ${ }^{58}$.

'Zina eden kişinin mümin olduğu halde zina etmeyeceği.....' hadisi ${ }^{59}$.

'Cebrail(a.s.)'in insan kılığında, Hz. Peygamber (a.s.)'e, iman, islâm ve ihsan'dan sormasina dair hadis ${ }^{60}$.

'Allah arş üzerinde kemaline yaraşır şekilde, hulûl etmeden, keyfiyetsiz, teşbihsiz, cisimsiz, semâvâtı üzerindedir.' hadisi ${ }^{61}$.

'Cesedin yok olmasıyla ruhların yok olmayacağı ve baki kalacağı...'na dair hadisler ${ }^{62}$.

'Meleklerin kabirde sual sormaları...'na dair hadis ${ }^{63}$.

'Kabir azabının varlığı, kabir azabından, sığınmayı ve kabir nimetlerini....' anlatan hadisler ${ }^{64}$.

'Sırat, mizan, azaların konuşması, cennet ve cehennemin durumu ve el'an, şimdiki halde yaratılmış olması, amellerin tartılması ....' na dair hadisler ${ }^{65}$.

'Havz' hadisi. ${ }^{66}$.

Hadîsi'l-Mütevâtire adını verdiği bu kitapta mütevâtir hadisleri bâblarına ve senetlerine göre tertip etmiş, sonra da her râvînin hadisleri nasıl tahric ettiğini göstermek üzere Katfu'l-Ezhâr isimli kitabını telif edip bu kitapta da mütevâtir hadisleri ele almıştır (es-Suyutî, Tebrîbu'r-Râvî, Şerhu Takribi'n-Nevevî, s. 373).

${ }^{57} \mathrm{Bu}$ anlamda birçok hadisin mevcut olduğunu ve değişik lâfızlarla ulaştığını anlatan Kettanî, buradaki tevatürün manevî olduğunu söyler. Bu hadis Suyûtî'nin el-Ezhâr'ında da mevcuttur (el-Kettânî, Nazmu'l-Mütenâsir fi'lHadîsi'l-Mütevâtir, s.28vd.).

58 el-Kettânî, a.g.e., s.29

59 el-Kettânî, a.g.e., s.30

${ }^{60}$ el-Kettânî, a.g.e., s.30vd.

${ }^{61}$ Bu hadisin mütevâtir olduğunu İbn Teymiye (v.728/1327) de kabul etmektedir (el-Kettânî, a.g.e., s.31vd.).

62 el-Kettânî, a.g.e., s.82

${ }^{63}$ el-Kettânî, a.g.e., s.82vd.

${ }^{64} \mathrm{Bu}$ konuda lafzî mütevâtir hadisler vardır diyenler olduğu gibi, manevî mütevâtir hadislerin varlığını kabul edenler de olmuştur (el-Kettânî, a.g.e., s.84).

${ }^{65} \mathrm{Bu}$ çeşit hadisler manevî mütevâtir ile sabit olmuştur. İbnü'l-Cevzî(v.597/1201), hesab'a dair olan hadisin mütevâtir olduğunu kabul eder (el-Kettânî, a.g.e., s.148). 
'Allah'ın ahirette görüleceği....'ne dair hadis ${ }^{67}$.

Subhi es-Salih'e göre, âlimlerin bir kısmının lafzî mütevâtire örnek olarak ileri sürdükleri bazı hadisler, aslında manevî mütevâtir olan hadislerdir. Fakat muhtevalarının şöhret bulup yayılması, lafızlarında mevcut olan rivayet ihtilâflarını kapatmıştır. Dolayısıyla bu durum onların lafzî mütevâtir olarak kabul edilmelerini sağlamıştır. Yine manevî mütevâtirlerin birçoğu aslında âhad haberlerdir. Fakat birinci tabakadan sonra şöhrete erişmesinde bir mahzur görmeyen hadis âlimleri bu nevi haberleri manevî mütevâtir kabul etmişlerdir. Örnek olarak, 'ameller niyetlere göredir' hadisini, hadis âlimleri manevî mütevâtir olarak kabul ederler. Hâlbuki onu yalnız Ömer b. Hattâb, ondan yalnız Alkame, ondan yalnız Muhammed b. İbrahim et-Teymî, ondan da yalnız Yahya b. Saîd el-Ensârî rivayet etmiş ve hadis ancak Yahya ile meşhur olmuştur ${ }^{68}$.

Âmidî(v.631/1233), Gayetü'l-Merâm adlı eserinde lafız ve senet bakımından âhad olup, ümmetin ameli ile üzerinde birleşilen ve böylece bir nevi tevatür mertebesine ulaşan haberlerin mevcut olduğunu ve bu nevi haberlerin kesin ilmin meydana gelmesi konusunda tevatür muamelesi göreceğini anlatır ${ }^{69}$. Gazzâlî (v.505/1111) de el-ikktisâd adlı eserinde bu düşünceye katılmaktadır ${ }^{70}$.

\section{B- Haber-i Vâhid}

a-Tarifi

Tevâtür veya şöhret derecesine ulaşmayan, bir, iki veya daha fazla kişi tarafından rivayet edilen haberlere, âhad haberler denir ${ }^{71}$. Cürcânî(v.816/1413), haber-i vâhid öyle bir sözdür ki onu Resûlullah (a.s.)'tan bir kişi duymuş, ondan da bir kişi duymuş, ondan da bir kişi duymuş ve bu durum hadisle amel eden kişiye kadar devam etmiştir diye haber-i vahidi tarif etmişse $\mathrm{de}^{72}$, bu nevi haberlerin bir veya iki kişi tarafından rivayet edilmiş olması şart değildir. Haber bir kişi tarafından rivayet edilebileceği gibi, iki, üç ve daha fazla kimseler tarafından da rivayet edilebilir. Bu bakımdan haber-i vâhidin tarifinde ravi sayısı kaç olursa olsun, mütevâtir mertebesine ulaşmamış haberler demek daha doğru olur $^{73}$.

\footnotetext{
${ }^{66}$ Suyûtî, havz hadisinin elli sahabe tarafından rivayet edildiğini, Kâdî İyâz(v. 544/1149)'in da bu hadisi mütevâtir olarak kabul ettiğini söylemektedir (el-Kettânî, a.g.e., s.151vd; Suyûtî, Tebrîbu'r-Râvî, Şerhu Takribi'n-Nevevî, s.373vd.).

${ }^{67}$ el-Kettânî, a.g.e., s. 153

${ }^{68}$ Subhi es-Sâlih, Ulûmu'l-Hadîs, s. 150

${ }^{69}$ el-Âmidî, Gayetü'l-Merâm fì İlmi'l-Kelâm, s.365

${ }^{70}$ el-Gazzâlî, el-ìktisâd fi' 'l-i't tikâd, s.208vd.

${ }^{71}$ Abdülazîz el-Buhârî, Keşfu'l-Esrâr, II/690; es-Suyûtî, Tebrîbu'r-Râvî, Şerhu Takribi'n-Nevevî, s. 375

${ }^{72}$ el-Cürcânî, et-Ta'rîfât, 'el-haber' md.

${ }^{73}$ Talât Koçyiğit, Hadiscilerle Kelâmcılar Arasındaki Münakaşalar, s. 244
} 
b-Şartları

Birinci hicri asırda, hadislerin kaleme alınmayıp vahyin başlangıcından Resûlullah (a.s.)'ın irtihaline kadar geçen yirmi üç yıl zarfında Peygamber Efendimizin söyleyip, yaptıklarının kayıt altına alınarak daha sonraki nesillere aktarılması konusunda açık bir tasarrufta bulunmaması ve bu hususta ashabın bir bakıma yalnız hafızalarına güvenmesi sonucu, bazı kimselerin kendi uydurmalarını yalan olarak Peygamber (a.s.)'e isnatlarına neden olmuştur. Hatta bu uydurmaların daha Resûlullah (a.s.)'ın hayatında başladığı anlaşılmaktadır $^{74}$. Bunun sonucu olarak fıkıh ve kelâm âlimleri, mütevâtir mertebesine ulaşmayan haber-i vâhidin sıhhatinin tespit edilmesi için bir takım şartlar öne sürmüşler, bu şartlara uyan haberlerle amel etmişler veya hüküm vermişlerdir.

Haber-i vâhid için ağır kabul edilebilecek şartlar öne sürenlerden biri Ebu Hanîfe(v.150/767)' dir. Ebu Hanîfe zamanında hadis uydurma hareketinin inanılmaz derecede yaygın olduğunu anlatan Subhi es-Salih; 'Ebu Hanîfe'nin re'yi ve kıyâsı bir takım hadislere tercih ederek bunlara önem vermesini ve haber-i vâhidlerin çoğunu reddetmesini büyük ölçüde doğal karşılarız. Zaten re'y imamı olan birinin hadisleri kabul ederken bazen bir kısmında aşırı davrandığı ağır şartlar ileri sürmesi gerekirdi’ demiştir ${ }^{75}$.

Şehristânî(v. 54-8/1153) de el-Milel ve'n-Nihal adlı eserinde, Ebu Hanife'nin haber-i vâhidlere karşı tutumunu yaklaşık ifadelerle anlatır ${ }^{76}$. Âmidî, İmâm-1 Azam'ın, haber-i vahidi rivayet eden râvide olması gereken şartları iki olarak kabul ettiğini belirtir. Bu şartlara göre:

a) Râvînin Müslüman olması,

b) Fasık bir kimse olarak tanınmamış olması gerekir ${ }^{77}$.

Subhi es-Salih'in naklettiği Ebu Hanife'ye ait şartlar ise çok daha geniş ve o derece ağırdır. Ona göre, Ebu Hanîfe'nin haber-i vâhid için şartları şöyle sıralanabilir:

a) Haber-i vahidin, şeriatın kaynaklarında yapılan istikrâdan sonra ittifak edilen şartlara muarız olmaması,

b) Kur'an'ın genel prensiplerine ve zahirine muhalif olmaması,

c) Sözlü veya fiilî olan meşhur sünnete aykırı olmaması,

d) Ravinin hadis müzâkere etmedikçe yazısına güvenmemesi,

e) Bir beldeye ait olmadan, sahabe ve tabiinden tevarüs edilen amele muhalif olmamas1,

f) Ravinin, hadisin zıddıyla amel etmemesi,

g) Hadisin, metinde veya senette bir fazlalık ile infirâd etmemesi,

\footnotetext{
${ }^{74}$ Ahmed Emîn, Fecru'1-İslâm, s.311

${ }^{75}$ Subhî es-Salih, Ulûmu'l-Hadîs, s. 308

${ }^{76}$ eş-Şehristânî, el-Milel ve'n-Nihâl, I/207

77 el-Âmidî, el-İhkâm fî Usûli'1-Ahkâm, II/70
} 
h) Herkesin başına gelebilecek bir mesele olmaması gerekir ${ }^{78}$.

İmâm-1 Şâfiî(v.204/819), sünnetin en kuvvetli savunucularından birisidir. Buna rağmen, hadisin sıhhatini garanti edebilmek için bazı şartlar ileri sürmüş ve ancak bu şartlara uyan hadislere itibar edileceğini ${ }^{79}$ de belirtmiştir. Şafîi'nin şartları şöylece sıralanabilir:

a) Mütevâtir olmayan hadisin râvisi, sika, doğru, ne dediğini ve hadisin manasını değiştirecek sözleri bilmelidir,

b) Râvi, hadisin manasını tam olarak bilmiyorsa, hadisi mana yoluyla değil, asıl lâfızları ile rivayet etmelidir,

c) Râvi, rivayetini hıfzetmiş olmalıdır,

d) Râvi, sika râvilerle muhalefet ve tedlîsten uzak bir kimse olmalıdır,

e) Hadis, ilk kaynağına varıncaya kadar aynı şartları taşıyan râviler tarafından rivayet edilmiş olmalıdır ${ }^{80}$.

Âmidî(v.631/1233)'nin aynı konudaki şartları dört madde halinde toplanabilir:

a) Râvinin mükellef olmas1,

b) Müslüman olması,

c) Duyduğu haberi ezberlemesi, unutma ihtimalinden daha kuvvetli ve tercihe şayan olması,

d) Adalet sıfatı ile vasıflanmış olması gerekmektedir ${ }^{81}$.

$$
\text { c-Çeşitleri }
$$

Âhad haberler değişik yönlerden sınıflandırmalara tabi tutulmuşlardır. Bunlardan biri, Peygamber (a.s.)'den nakledilen haberlerin, sahih, hasen, zayıf şeklinde yapılan üçlü sınıflandırmadır. İbn Teymiye(v.728/1327)'nin, bu sınıflandırmanın Ebû İsâ et-Tirmizî'ye ait olduğunu, ondan önce bilinmediğini naklettiğini Muhammed Ebû Zehra'dan öğrenmekteyiz ${ }^{82}$. $\mathrm{Bu}$ sınıflandırmada mütevâtir haberler, tevatür sebebiyle her hangi bir senet iradından müstağni olduklarından dolayı, hadis uleması mütevâtir haberleri araştırma konuları içine almamışlardır ${ }^{83}$.

Mütevâtir mertebesine ulaşmayan haber-i vahidin ayrı bir sınıflandırması da, meşhur, azîz ve garîb şeklindeki üçlü sınıflandırmadır ve daha çok kabul görenidir.

\footnotetext{
${ }^{78}$ Subhi es-Salih, Ulûmu'l-Hadîs, s. 308

${ }^{79}$ Hayreddin Karaman, İslâm Hukukunda İctihâd, s.145

${ }^{80}$ eş-Şâfîi, er-Risâle, s. 370 vd.

${ }^{81}$ el-Amidî, el-İhkâm fî̀ Usûli'1-Ahkâm, II/64 vd.

${ }^{82}$ Muhammed Ebû Zehra, Ahmed b. Hanbel, s. 235

${ }^{83}$ es-Suyûtî, Tebrîbu'r-Râvî, Şerhu Takribi'n-Nevevî, s. 371
} 
a) Meşhur haber: Başlangıçta âhad iken, ikinci asırda şöhret bulmuş ve yalan üzerine ittifaklarını aklın kabul etmeyeceği bir topluluk tarafından nakledilmiş olan haberdir $^{84}$. Cürcanî, meşhur haber öyle bir sözdür ki, onu Hz. Peygamber (a.s.)'den bir kişi duymuş, bu tek şahıstan bir topluluk, o topluluktan da bir başka topluluk duyarak, durum hadisle amel eden kişiye kadar bu şekilde devam etmiştir diyerek, meşhur haberin daha geniş bir tarifini yapmıştır ${ }^{85}$.

b) Garîb haber: Bir ravi, bir hadisi meşhur bir zattan rivayette yalnız kalırsa, rivayet ettiği bu çeşit haberlere garîb adı verilir ${ }^{86}$. Buradaki yalnız kalma (infirâd), bir şahsın bulunuşu demek değildir. Raviler şöhret derecesine varamadığı sürece, müteaddit olsalar dahi infirâd vardır. Buradaki garabet, o hadisin, aynı meşhur zattan hadis almış olan diğer ravilere meçhul kalmasıdır ${ }^{87}$.

c) Azîz haber: Garîb hadislerdeki infirâd eğer iki veya üç kişi tarafından vuku bulmuş ise böyle hadislere azîz adı verilir ki bu nevi haberler sünnet içinde hemen hemen bulunmaz ${ }^{88}$.

d- Akâid sahasındaki haber-i vâhidler

Muhammed Ebu Zehra, Ahmed b.Hanbel'in sünnete karşı olan tutumunu anlatırken dolaylı yoldan konuya girer ve bize Ahmed b. Hanbel'in, Müsedded el-Basrî'ye gönderdiği bir mektuptan bahseder. Bu mektupta geçen, mîzan, sırât, havz, şefâat, arş, kürsî, ölüm meleğinin varlığı, surun üfürüleceği, deccâl'in bu ümmetin haricinde olduğu, Meryem oğlu İsa'nın yeryüzüne ineceği ve deccâli öldüreceğine dair haberlerin (Ahmed b.Hanbel'e göre bu hususlara inanmak haktır) pek çoğu Ebu Zehra'ya göre âhad haberlerle sabit olmuştur. Yine, kabir azab1, münker ve nekir, havz, şefâat, muvaahidlerin bir müddet azaptan sonra ateşten çıkarılacaklarına dair haberler Ebu Zehra'ya göre âhad haberlerdir ${ }^{89}$.

Yukarıda adı geçen konulardan bir kısmına daha önce akâid sahasındaki mütevâtir haberler başlığı altında Kettânî'nin eserinde rastlanmıştı. Bu durumda Subhi es-Salih'in değerlendirmesi her halde ayrı bir önem kazanacaktır.

\section{III- Ehl-i Sünnet'e göre Haber-i Mütevâtir ve Haber-i Vâhid'in değeri}

Ehl-i Sünnet bünyesinde, mütevâtir haberin değeri ve kesin ilim ifade etmesi konusunda bir fikir ayrılığı söz konusu değildir. Mütevâtir haberlerin yakînî ilim

\footnotetext{
${ }^{84}$ Abdülazîz el-Buhârî, Keşfu'1-Esrâr Şerhu Usûli’1-Pezdevî, II/688

85 el-Cürcânî, et-Ta'rîfât, 'el-haber' md.

${ }^{86}$ es-Suyûtî, Tebrîbu'r-Râvî, Şerhu Takribi'n-Nevevî, s.375

${ }^{87}$ Ali Osman Koçkuzu, M. Yaşar Kandemir, Hadis Ders Notlarl, s.57

${ }^{88}$ es-Suyutî, a.g.e, s.375

${ }^{89}$ Muhammed Ebu Zehra, Ahmed b. Hanbel, s. 226
} 
gerektirdiği ve bu tür haberlerden şüphe edilemeyeceği konusunda Ehl-i Sünnet âlimleri ittifak halindedirler ${ }^{90}$.

Mütevâtir derecesine ulaşmayan haber-i vâhid hususunda özellikle ilim ifade etmeyeceği konusunda ihtilâf mevcut olduğundan, Ehl-i Sünnet'e göre haber-i mütevâtir ve haber-i vâhidin değeri başlığı altında incelenecek olan bu bölümde, hakkında ihtilâf bulunmayan mütevâtir haberin değerinin kısaca belirtilmesi ve Selefiyye, Ehl-i Sünnet kelâmcıları ve Yeni İlm-i Kelâm Devri yan başlıkları altında da yalnızca haber-i vâhidin değeri üzerinde durulması uygun görülmüştür.

Selefiyye'ye göre, haber-i vâhidin değeri konusunda iki ayrı görüş hâkimdir. Bir kısmı haber-i vâhidin kesin ilim ifade edeceğini savunurken, diğer bir kısmı da haber-i vâhidin başlı başına ilim ifade etmeyeceğini, ancak bir karine ile desteklendiği zaman ilim ifade edebileceğini, savunur ${ }^{91}$.

Hadis âlimlerine göre haber-i vâhidin karine ile desteklenmesi demek, o haberi kuvvetlendirecek bazı özelliklerin bulunması demektir. Bu özelliklerden bazıları, aynı haberin değişik yollardan gelmesi, haberi rivayet eden ravilerin, diğer haber-i vâhidlerin ravilerinde bulunmayan bazı özelliklere sahip olması, haberin Buhârî(v.256 h.) ve Müslim (v.261 h.)'in kitaplarında yer alması vb.dir. Bu tür haberlerin, bazı kelâmcılar nazarında da ilim ifade edebileceği görülecektir. Ancak kelâmcıların karine anlayışı hadis âlimlerinden farklıdır. Kelâmcılara göre karinenin ne olduğu Cüveynî(v.478/1085)'nin haber-i vâhid hakkındaki değerlendirmesinin verilişi sırasında görülecektir.

Ehl-i Sünnet kelâmcıları arasında haber-i vâhidin değeri konusunda bir ihtilâf söz konusu değildir. Gerek Mâtûrîdiyye ve gerekse Eş'ariyye kelâmcıları, haber-i vâhidin başlı başına ilim ifade etmeyeceğini, ancak bir karine ile desteklendiği zaman ilim ifade edeceğini savunurlar. Bundan dolayı, Mâtûrîdiyye ve Eş'ariyye kelâmcıları ayrı başlıklar altında incelenmemiş, Ehl-i Sünnet kelâmcıları başlığı altında vefat tarihleri göz önünde bulundurularak incelemeye tabi tutulmuştur.

Selefiyye, Mâtûrîdiyye ve Eş'ariyye kelâmcılarının bir nevi devamı özelliklerini taşıyan yeni devir mümessilleri ise Yeni İlm-i Kelâm Devri yan başlığı altında incelenmiş ve haber-i vâhid hakkındaki görüşleri tespit edilip, belirtilmeye çalışılmıştır.

\section{A-Selefiyye}

a. Haber-i vâhidin ilim ifade ettiğini savunanlar

\footnotetext{
90 el-Matûrîdî, Kitâbu't-Tevhîd, s.9; el-Bâk1llânî, Kitâbu't- Temhîd, s.383 vd; el-Cüveynî, el-İrşâd ilâ Kavâtı''1Edille fî Usûli'l-İ'tikâd, s.412 vd; el-Gazzâlî, el-İktisâd fi'l-İ'tikâd, s.21; en-Nesefî, Tebsıretu'1-Edille, vr.6a; İbn Teymiye, Ref'u'l- Melâm, s.99; el-Âmidî, el-İhkâm fî Usûli'1-Ahkâm, II/24 vd.

${ }^{91}$ el-Âmidî, el-İhkâm fì Usûli'1-Ahkâm, II/32
} 
Sünnetin, Kur'an'ın mutlak açıklayıcısı olduğunu ve Kur'an ilminin ancak sünnet ile elde edileceğini söyleyen Ahmed b. Hanbel ${ }^{92}$ (v.241/855)'e göre haber-i vâhid kesin ilim ifade eder.

Âmidî, Ahmed b.Hanbel'den rivayet edilen haber-i vâhid hakkındaki iki görüşten birinin, haber-i vâhidin yakinî ilim ifade ettiği yönünde olduğunu söylemektedir ${ }^{93}$.

Ebû Ya'lâ(v.307/919)'nın Tabakâtu'l-Hanâbile adlı eserinde, Ahmed b.Hanbel'e göre haber-i vâhidin ilim ifade etmesi hususunda açık bir nakline rastlanmamaktadır. Ebû Ya'lâ, Ahmed b.Hanbel'in görüşlerini naklederken 'Haber-i vâhid ile amel etmek şarttır. Şartlar açısından mütevâtir haber için düşünülmesi mümkün olmayan şeyler, haber-i vâhid için mümkündür. Ancak, haberi nakledende mevcut olabilecek hüsnü zan ve ravideki bilgisizlik hoş karşılanırr ${ }^{94}$ demektedir. Yine haber-i vâhide muhalefet eden kişinin Ahmed b. Hanbel'e göre fâsık olduğunu Ebû Ya'lâ'dan öğrenmekteyiz ${ }^{95}$.

Abdülaziz el-Buhârî, hadis ehlinin çoğunluğunun ve Ahmed b. Hanbel'in mezhebinin, haber-i vâhidin yakinî ilim ifade ettiği ve kendisiyle kesin bilgi elde edileceği görüşünde olduklarını anlatır ${ }^{96}$.

Şer'î hükümler konusunda Allah'ın delillerinin beş usulden ${ }^{97}$ alınmış olduğunu kabul eden Ahmed b.Hanbel ${ }^{98}$, e göre, haber-i vâhidin kesin ilim ifade ettiğini nakledenlerden biri de Muhammed Ebû Zehrâ'dır. Ahmed b.Hanbel adlı eserinde bu konuda şunları nakleder:

'Ahmed b.Hanbel'in itikada ait tedrisleri, selefin metodu ile ilgili fikirleri, devrinde yaşayanların kendisine sordukları sorulara verdiği cevaplar, bize onun itikâdî konularda da haber-i vâhidleri delil olarak aldığını göstermektedir. Kabir azabına, münker ve nekir'e, havz, şefaat, muvahhidlerin bir müddet azaptan sonra ateşten çıkarılacaklarına dair haberleri o, tamamen sünnetten almıştır. Bu durum, onun sünnete olan sevgisinden dolayı dinî olan her hususu sünnetten ve hadislerden aldığını gösterir. Çünkü bunlar âhâd haberlerdir ${ }^{99}$,'

Haber-i vâhid İbn Hazm(v.45b/1063)'e göre de başlı başına ilim ifade eder. İbn Hazm, el-İhkâm adlı eserinde Resûlullah(s.a.)'a varıncaya kadar, adil kimselerin rivayet ettiği haber-i vâhidin hem ilim ve hem de amel ifade edeceğini söylemektedir ${ }^{100}$. Daha sonra haberi vâhidin amelin yanı sıra ilmi gerektireceğine dair deliller ileri süren İbn Hazm $^{101}$ :

\footnotetext{
${ }^{92}$ Muhammed. Ebû Zehrâ, İbn Teymiye, S.458

${ }^{93}$ el-Âmidî, el-ïhkâm fî Usûli' 1-Ahkâm, II/32

${ }^{94}$ Ebû Ya'lâ, Tabakâtu'l-Hanâbile, II/286

${ }^{95}$ Ebû Ya'lâ, a.g.e., II/304

${ }^{96}$ Abdülaziz el-Buhârî, Keşfu' 1-Esrâr Şerhu Usûli' 1-Pezdevî, II/691

${ }^{97}$ Kitap, Sünnet, Sahabe Kavli, Sahabe İhtilâfı, Kıyas.

${ }^{98}$ Ebû Ya'lâ, a.g.e., II/283vd.

${ }^{99}$ Muhammed Ebû Zehrâ, Ahmed b. Hanbel, s.226

${ }^{100}$ İ̉n Hazm, el-İhkâm fì Usûli' 1-Ahkâm, I/97

${ }^{101} \mathrm{I} b n$ Hazm, a.g.e, $\mathrm{I} / 109 \mathrm{vd}$.
} 
“(Peygamberler), apaçık mucizeler ve kitaplarla (gönderildiler). İnsanlara, kendilerine indirileni açıklaman için sana da bu Kur'an'1 indirdik. Umulur ki düşünüp $\operatorname{anlarlar}^{102,}$,

“Ey Resûl; Rabbinden sana indirileni tebliğ et. Eğer bunu yapmazsan, O’nun elçiliğini yapmamış olursun. Allah seni insanlardan koruyacaktır. Doğrusu Allah, kâfirler topluluğuna rehberlik etmez ${ }^{103}$ ", ayetlerini delil olarak naklettikten sonra şu şekilde devam eder:

"Bu ayetlere dayanarak, haber-i vâhidin ilim ifade etmediğini söyleyenlere şöyle bir soru yöneltiriz. Resûlullah (s.a.) kendisine indirileni açıkladı mı yoksa açıklamadı mı? Kendisine indirileni tebliğ etti mi yoksa etmedi mi? Bunlardan birinin mutlaka olması gerekir. Hâlbuki haber-i vâhidin ilim ifade etmediğini söyleyenler, Resûlullah(s.a.)'ın kendisine indirileni tebliğ edip insanlara açıkladığını ve bununla tebliğ ettiği kişilere hüccet getirdiğini söylemektedirler. İște o zaman bu tebliği onlara sorarız. Bu tebliğ ve beyan bizim zamanımızdan kıyamete kadar bakî midir, değil midir? Eğer onlar, bakîdir ve kıyamete kadar bâkî kalacaktır, derlerse zaten sözümüze gelmiş olacaklardır. Aynı zamanda onlar, Allah'ın dinde indirmiş olduğu her şeyin, indirmediğini açıklayıcı olduğunu ve kıyamete kadar tebliğ edici olduğunu da ikrar etmiş olacaklardır. İşte bizim kendisi gibi adîl kişiden Peygamber (s.a.)'e kadar muttasıl bir senetle rivayet olunan haberi vâhidin hem ilim ve ameli gerektireceğine dair delilimiz budur ${ }^{104,}$ der.

İbn Hazm'ın delilinde görülen, Hz. Peygamber (a.s.)'ın kendisine ulaşanı tebliğ edip etmemesi konusu başka, haber-i vahidin Resûlullah(s.a.)'a olan nispetinin kesin olmayışı nedeniyle kelâmcılar tarafından itikâdî konularda delil kabul edilmemesi konusu ise daha başkadır. Yoksa hiç bir Ehl-i Sünnet kelâmcısının, Resûlullah(a.s.)'ın kendisine indirileni açıklamadığını savunduğuna rastlamak mümkün değildir.

Muhammed Ebû Zehrâ da, haber-i vâhidin İbn Hazm'a göre kesin ilim gerektirdiğini anlatır ve İbn Hazm'ın Hz. Peygamber (s.a.)'ın sözlerini, amelî konularda kabul ettiği gibi, itikâdî konularda da kabul ettiğini, bundan dolayı onun nazarında mütevâtir haberle, haber-i vâhidin aynı değerde olduğunu söylemektedir ${ }^{105}$.

Haber-i vâhidin kesin ilmi gerektirdiğini kabul edenlerden biri de Şeyhülislâm İbn Teymiye(v.728/1327)'dir. Ref'u'l-Melâm ani'l-Eimmeti'l- A'lâm adlı eserinde, hadislerin değerlendirmesini yapan İbn Teymiye hadisleri, delâleti kat'i olanlar (mütevâtirler) ve delâleti açık fakat kat'i olmayanlar diye iki kısma ayırdıktan sonra, ikinci kısımdaki hadislerle (haber-i vâhid) amel etme konusunda ümmetin ittifak halinde

\footnotetext{
${ }^{102}$ Nahl Sûresi (16), 44

${ }^{103}$ Mâide Sûresi(5), 67

${ }^{104}$ İbn Hazm el-İhkâm fî Usûli' 1-Ahkâm, I/112

${ }^{105}$ Muhammed Ebû Zehrâ, İbn Hazm, s.181 vdd.
} 
olduğunu söylemektedir. Ancak bazı kelâm âlimleri nazarında bu tür hadisler ilim ifade etmez. Bunun nedeni, bu tür haberlerin rivayet yollarını bilen, râvilerin durumlarına aşina olan, haberle birlikte bulunan birçok karine ve alâmetlerden yararlanan bir kişi için bu haberler kesin ilim ifade ederken, bu hususları bilmeyene göre kesin ilim ifade etmez. Bundan dolayı, hadis ilminin mütehassısları nazarında haber-i vâhidler kesin ilim ifade ederken, diğer bazı âlimlerce değil kesin ilmi gerektirmek, bu hadislerin sahih olmadığı dahi zannedilmiştir ${ }^{106}$.

Haber-i vâhidlerin şer'î hüküm ve amellerde kaynak olabileceğinde muteber olan âlimlerin ittifakının olduğunu, ancak uhrevî bir cezayı haber vermek (vaîd) gibi ilim ve itikat ifade eden meselelere ait haber-i vâhidler hususunda, ihtilâfın mevcut olduğunu anlatan İbn Teymiye ${ }^{107}$, bu konudaki görüşleri ve bunlara ait delilleri de açıklamıştır.

Birinci grupta yer alanlar, vaîd ifade eden haber-i vâhid ile ancak haberde konu edilen fiilin haram olduğuna hükmedilebilirse de, itikat ve ilim açısından kesinlik arz etmedikçe bu haberlerin kaynak olamayacağı görüşünü savunanlardır. Çünkü onlara göre vaîd, itikat ve ilim sınırları içindedir. Bunlar ise ancak ilim ifade eden yol ve vasitalarla sabit olabilir. Bu haberlerin delâlet ve ifadeleri kesin olmadığı sürece, haberde konu edilen vaîd'in gerçekleşmesi de kesin olmaz ${ }^{108}$.

İkinci grupta yer alanların, haber-i vâhidlerin ifade ettikleri vaîd konusunda da delil ve kaynak olduğunu savunanlar olup, bütün Selef'in de aynı görüşte olduğunu anlatan İbn Teymiye, bu görüşü savunanların delillerini de şöyle anlatır:

'Vaîd de şer'î hüküm ve kaidelerin bir kısmını teşkil eder. Şer'î hükümler ise bazen kesin, bazen kesin olmayan delillerle sabit olup, bilinir. Çünkü matlup olan, vaîd'in her işleyen hakkında kesin olarak tahakkuk edeceğine şüphesiz olarak inanmak değil, ister kesin, ister zann-1 gâlib derecesinde olsun bir inanç elde etmektir. Nitekim amelî ve fiilî hükümlerde de durum aynıdır. Bir kimsenin belirli bir fiili, Allah'ın yasak ettiğine ve işleyeni de genel anlamda tam açıklanmamış bir ceza ile tehdit ettiğine inanması ile zikredilen fiili Allah'ın haram kıldığına ve işleyeni de belirli ve kesin bir ceza ile cezalandıracağını bildirdiğine inanması arasında bir fark yoktur. Bunlar Allah'tan nakledilen birer konu olma hususunda birleşirler. Herhangi bir delille Allah'tan, gerek birinci ve gerekse ikinci nev'iden haberler nakledilebilir. Hatta bu çeşit haberlerle vaîd hususunda da amel, uygun bir harekettir demek daha doğru olur. Çünkü tehdit ve ceza haberinin gerçekleşeceğine inanmak, insanları bazı fiilleri terk etmeye sevk eder. Eğer bu vaîd doğru ise, insan kurtulmuş olacaktır. Eğer vaîd aynen gerçek değil de ceza biraz daha hafif ise, bu cezanın daha ağır olduğuna inanmak suretiyle

\footnotetext{
${ }^{106}$ İbn Teymiye, Ref'u'l-Melâm ani'l-Eimmeti'l- A'lâm, s. 99

107 İbn Teymiye, a.g.e, s. 100

108 İbn Teymiye, a.g.e., s.100vd.
} 
meydana gelen hata, bundan dolayı kötü fiili terk etmiş kişiye zarar vermeyecektir. Çünkü aynı şahsın zikredilen cezanın daha hafif olduğuna inanması veya hiç inanmaması halinde gerçeğe oranla hata etmesi mümkündür. Bu ikinci hata ise, kişinin gözünde yasak fiili küçümseteceğinden, onu işlemesine neden olacak, dolayısıyla cezaya çarptırılacak veya müstahak olacaktır. Buna göre, cezanın varlık veya yokluğunda hata eşit, hâlbuki cezanın varlığında, inanç bulunduğu takdirde kurtuluş daha çok mümkün olacaktır. Böylece inanmanın daha hayırlı olduğu da ortaya çıkmaktadır. İşte bu delile dayanarak âlimlerin çoğu, haram kılan ve yasaklayan delili, mubah kılan delile tercih etmişlerdir $^{109}$, diyerek bu konudaki görüşlerini nakleden İbn Teymiye, her hangi bir fiille ilgili vaîd ve tehdidin, mütevâtir olarak naklinin gerekli olmadığını da ayrıca belirtmektedir ${ }^{110}$.

Subhi es-Salih de haber-i vâhidin kesin ilim gerektirdiği fikrini savunur. Ona göre:

'Hadis âlimlerinin çoğu, sahih hadisin kesinlik ifade edebilmesi için Buhârî (v.256h.) ve Müslim(v.261h.) tarafından tahric edilmiş olması gerekir, derler. Bir kısım hadis âlimleri ise, sahih olan haber-i vâhidin, lafzî ve manevî mütevâtir hadis gibi kesin ve yakinî ilim ifade ettiğini kabul ederler. Kabul edilmesi gereken görüş, İbn Hazm (v.456/1063)'ın görüşüdür. Zira yalnızca sahihayn hadislerinin kesinlik ifade ettiğini söylemek anlamsızdır. Bu iki kitabın dışında kalan kitaplardan sıhhati kesin şekilde bilinenleri de aynı şekilde kabul etmek gerekir. Bunların Müslümanlar nazarında büyük bir değere sahip olması, diğer kitaplardaki sahih hadislerin değerini küçümsemeyi gerektirmez. Aynı şekilde sıhhati kesinleştikten sonra, haber- i vâhidin zan ifade ettiğini söylemenin de bir anlamı yoktur. Çünkü bir hadisin sahih olabilmesi için aranan şartlar, ondaki zan manalarını ortadan kaldırır ve onun hakkında kesin ilim hâsıl olmasını gerektirir $^{111}$.

b. Haber-i vâhidin ilim ifade etmediğini savunanlar

Mütevâtir mertebesine ulaşmayan haber-i vâhidin kesin bir delil olarak kullanılabilmesi problemi ikinci hicrî asırdan itibaren devam edip, tartışmaların sürmesini sağlamıştır.

İmam Şafiî zamanında, haber-i vâhidin ilim ifade edip etmeyeceğine dair bir problem mevcut olmayıp, yalnızca haber-i vâhid ile amel etme veya terk etme problemi söz konusudur. Dolayısıyla o, haber-i vâhidin ilim ifade edip etmemesi konusunda açık bir görüş beyan etmemiştir. Ancak er-Risâle adlı eserinde, haber-i vâhidin tespiti esnasında

\footnotetext{
${ }^{109}$ İbn Teymiye, a.g.e., s.101vd.

${ }^{110}$ İbn Teymiye, a.g.e., s.103

${ }^{111}$ Subhi es-Sâlih, Ulûmu'l-Hadîs, s. 151
} 
göz önünde bulundurulacak esasları göstermek için bir bölüm açmış ${ }^{112}$, ayrıca haber-i vâhidi rivayet eden râvide olması gereken vasıfları da anlatmıştır ${ }^{13}$. Daha sonra gerek Hz. Peygamber devrinde ve gerek vefatından sonra, ashabın haber-i vâhid ile amel edip kendi görüşlerini terk ettiklerini anlatan Şafîî ${ }^{114}$, özellikle Hz. Ömer'in, kendisine Hamel İbn. Mâlik'in rivayet ettiği ceninin diyetine dair hadis ${ }^{115}$ ile ed-Dehhâk ibn Süfyân'ın rivayet ettiği, kadının kocasının diyetine varis olmasına dair hadisi ${ }^{116}$ tetkik ederken, bu haberlerin, haberi rivayet eden ravilerin sıdkına güvenildiği zaman, kabul edilmesinin gerekliliğine delâlet edeceğini anlatır.

Eğer böyle bir haberin her hangi bir nedenden dolayı reddedilmesi gerekseydi, bunu Hz. Ömer'in yapmasının gerektiğini, hâlbuki Hz. Ömer'in gerek ed-Dehhâk'den ve gerekse Hamel İbn Mâlik'ten çok daha fazla Hz. Peygamber ile bulunduğunu, ayrıca bu ravilerin yanılma ve unutma ihtimallerinin de mevcut olduğunu belirten Şafî̂, bütün bunlara rağmen, Hz. Ömer'in kendi görüşünü terk ederek bu haberlere uyduğunu söyler. Sonuç olarak, kimsenin Hz. Peygamber'den gelen bir haber için, kendi görüşüne dayanarak nasıl ve niçin sorularını soramayacağını ve sözüne güvendiği kimsenin naklettiği haberi -ki o haber yalnızca o kimse tarafından rivayet olunmuş olsa bile- kabul etmemeye yetkili olmadığını anlatır ${ }^{117}$.

Fakat burada haber-i vâhid ile amel etmenin sahih oluşunun başka şey, haber-i vahidin kesinlik ifade etmesinin ise daha başka şey ${ }^{118}$ olduğu unutulmamalıdır.

Ayrıca Şafiî’nin çok kuvvetli bir sünnet taraftarı olmasının yanında, haberin Resûlullah (a.s.)'a nispetinin kesinliğini sağlama hususundaki çabası da dikkat çekicidir. Yoksa haber-i vâhid ile amel etme, genelde Ehl-i Sünnet'in ittifak ettiği bir konudur. Ancak, haber-i vâhidin, Peygamber (a.s.)'e olan nispeti kesinleşir, rivayet eden râvideki zan ihtimali ortadan kalkar ve bir karine ile desteklenirse, o zaman kendisi ile amel edilen haber-i vâhid aynı zamanda ilim de ifade edecektir. Dolayısıyla, Şafii'nin mütevâtir mertebesine ulaşmayan haber-i vâhidi bu denli geniş şekilde incelemesinin nedeni bu

\footnotetext{
112 eş-Şafîi, er-Risâle, s.401

113 eş-Şafîi, a.g.e., s.370

114 eş-Şafî̂, a.g.e., s.401, 402, 403, 406, 408, 410, 415, 416

115 Hamel İbn Mâlik’ten: 'Bir gün iki karımdan birisi hamile olan diğerine bir sopa ile vurdu da karnındaki ceninin ölü olarak düşmesine sebep oldu. Bu hadise üzerine Peygamber (a.s.), gurra ile yani vuranın diğerine bir köle veya cariye vermesine hükmetti."(eş-Şafî̀, er-Risâle, s.427)

116 ed-Dehhâk İbn Süfyân'ın Hz. Peygamber (a.s.)'in kendisine 'Eşyem ed-Dibâbî'nin diyetinden karısını varis kılmasını' yazdığını haber vermesi üzerine, 'kadın, kocasının diyetinden hiç bir şeye varis olamaz' diyen Hz. Ömer bu görüşünden vazgeçmişti. (eş-Şafiî, er-Risâle, s.429)

117 eş-Şafî̂, er-Risâle, s.429 (1179 no'lu paragrafın dip notu)

${ }^{118}$ Subhi es-Sâlih, Ulûmu'l-Hadîs, s. 311
} 
olmalıdır. Çünkü nassa dayalı olmayan içtihatların birleşmesinden ibaret olan icma dahi, Şafiî nazarında haber-i vâhidden daha zayıftır ${ }^{119}$.

Talât Koçyiğit, 'Âhâd Haberlerin Değeri' adlı çalışmasında, Şâfiî’nin haber-i vâhidi, dinde kesin hüccet olarak kabul ettiğini belirtmekte ise de ${ }^{120}$ Muhammed Ebû Zehra'nın eş-Şafiî adlı eserindeki şu değerlendirmesi dikkat çekmektedir:

'Şafiî, haber-i vâhidlere amelde hüccet olarak itibar etmekle birlikte, o, bu haberleri Kur'an ve mütevâtir derecesine koymamıştır. Haber-i vâhid ile ihticâcı, mütevâtir haberden daha aşağı derecede tutmuştur. Çünkü Kur'an ve mütevâtir sünnetin sübutu kat'idir. Bunlar hakkında şüphe etmek, şüphe edeni dinden çıkarır. Kitap ve mütevâtir sünnetin getirdiğini kabul etmekten kaçınan kişiye tövbe teklif edilir. Haber-i vâhid amelî hususlarda, amel edenleri bağlayıcıdır. Adil şahitleri reddetmenin mümkün olamayacağı gibi, bunları da reddetmek mümkün değildir. Fakat bu tür haberler infirâd yoluyla geldiği için, bu haber hakkında şüphe eden için tövbe et diyemeyiz. Her ne kadar yanlışlık yapmaları ihtimal dâhilinde ise de, adil şahitlerin şehadeti ile hükmedilebileceğini söyleyebiliriz. Fakat ravilerin görünüşteki doğruluklarına dayanılarak bu tür haberlerle hüküm verilir, bilinmeyen tarafları Allah'a birakılır ${ }^{121}$.

Burada görüldüğü gibi Şâfiî, haber-i vâhidi itikâdî konularda değil de amelî konularda hüccet olarak kabul etmektedir. Ayrıca haber-i vâhid hakkında şüpheye düşene ise azap gerekmediğine inanmaktadır.

Aslında Şafîînnin, er-Risâle'de geçen şu sözlerinden haber-i vâhidin ilim ifade etmediğini anlamak mümkündür. Ebû Zehrâ'nın değerlendirmesinin de aynı sözlere dayalı olduğu ortaya çıkmaktadır:

'İnsanların, üzerinde ittifak etmediği, âhâd yoldan gelen haberlerle hükmolunur. Bu hüküm için her ne kadar görünüşte hak ile hükmettiğimizi söyleyebilirsek te, gerçekte hak ile hükmettiğimizi söylememeyiz. Çünkü haberi rivayet eden râvinin yanılabilme ihtimali mümkündür ${ }^{122}$,

Haber-i vahidin kesin ilim ifade etmediğini savunanlardan biri de Hatib el-Bağdâdî (v.463/1070)' dir. el-Kifâye fî İlmi'r-Rivâye adlı eserinde, bir cemaat tarafından rivayet olunsa da tevatür özelliklerini taşımayan haber-i vâhidin ilim ifade etmeyeceğini söylemiştir ${ }^{123}$.

\footnotetext{
${ }^{119}$ Hayreddin Karaman, İslâm Hukukunda İctihâd, s. 145

${ }^{120}$ Talât Koçyiğit, 'Âhâd Haberlerin Değeri', s.136

${ }^{121}$ Muhammed Ebû Zehrâ, eş-Şâfîi, s.232

${ }^{122}$ eş-Şafîi, er-Risâle, s.599

${ }^{123}$ Hatîb Bağdâdî, el-Kifâye fì İlmi'r-Rivâye, s.16vd.
} 
Bağdâdî, eserinde, haber-i vâhidin kat'iyyet ifade ettiğini savunanları ${ }^{124}$ ve haber-i vâhidin ilim ifade ettiğini savunanları ${ }^{125}$ ayrı ayrı reddetmiştir. Ancak haber-i vâhid ile amel etmenin gerekliliğine inanan Bağdâdî, bu konuda da ayrı bir bölüm açmış ve sahih rivayetleri almıştır ${ }^{126}$. Haber-i vâhidin ilim ifade etmeyeceğine dair değerlendirmesi şöyledir:

'Kişilerin mükellef kılındığg dinî konularda, özellikle ilim ve kat'iyyeti gerektiren hususlarda haber-i vâhid kabul edilmez. Bunun nedeni şudur: Bir kimse bir haberin Resûlullâh(a.s.)'ın sözü olduğunu bilmez ise, o haber manası ile birlikte ilimden uzaktır. Lâkin Hz. Peygamber(a.s.)'in takrir edip, Allah'tan haber verdiği ve üzerimize ilmi gerektirmeyen diğer hükümlerde ise haber-i vâhid makbuldür ve kendisiyle amel vaciptir. Bu hususta, şer'an diğer mükellefler için varit olan haberlerle de amel gereklidir. Hadler, kefaretler, talak hükümleri, ramazan ve şevval hilâlleri, ıtak, hac, zekât, miras, alış-veriş, taharet, namaz vb. konular bunlara dâhildir. Aklın hükmüne, muhkem Kur'an'ın hükmüne, malum sünnete, sünnet yerine kaim fiile ${ }^{127}$ ve her türlü kesin delile aykırı olan konulardaki haber-i vâhid kabul edilmez ${ }^{128}$.

Subhi es-Salih, delâletinin zanna dayalı olmasından dolayı, Nevevî(v.676/1277)'nin de, haber-i vâhidin ilim ifade etmediği görüşünde olduğunu söylemektedir ${ }^{129}$.

Selefiyye'nin bir kısmı, haber-i vahidi amelî konularda olduğu gibi, itikadî konularda da delil olarak almışlar ve bu hususta haberler arasında mütevâtir ve âhad ayırımında bulunmamışlardır. Bu grup, haberin sahih şekilde Hz. Peygamber (s.a.)'den güvenilir yollar ve raviler tarafından ulaşmasını esas almışlardır.

Selefiyye'nin diğer kısmı ise, haber-i vâhidin başlı başına ilim ifade etmeyeceği fikrini savunmuşlardır. Bu çeşit haberleri amelî konularda kullanmışlar, fakat itikâdî konularda delil olarak kabul etmemişlerdir. Bunun nedeni, haber-i vahidin Peygamber (a.s.)'e ulaştığına dair kesin bir kanaat getirememelerinden dolayıdır.

\section{B. Ehl-i Sünnet Kelâmcıları}

$\mathrm{Bu}$ bölümde, fikirleri arasında bir ihtilaf bulunmadığından dolayı kelâmcıların, vefat tarihleri göz önünde bulundurularak inceleneceği daha önceden belirtilmişti.

\footnotetext{
${ }^{124}$ el-Bagdâdî, a.g.e., s.18 vd.

125 el-Bağdâdî, a.g.e., s. 25 vd.

126 el-Bağdâdî, a.g.e., s.26 vd.

127 Sünnet yerine kaim olan fiil, Medine ehlinin amelidir. İki kısma ayrılır. Hz. Peygamber (a.s.)'den nakil ve hikâye yolu ile ulaşan, amel ve içtihat veya istidlâl yolu ile meydana gelen amel. (Geniş bilgi için bk. İbn Kayyim, I'lâmu'l-Muvakkıîn an Rabbi'l-Âlemîn, II/361 vd.)

${ }^{128}$ el-Bağdâdî, el-Kifâye fì İlmi'r-Rivâye, s.432

${ }^{129}$ Subhi es-Salih, Ulûmu'l-Hadîs, s.151
} 
İmam Eş'arî(v.324/936)'nin haber-i vahidin değeri hakkında açık bir ifadesine rastlanılmamaktadır. Ancak Eş'arî'nin haber-i vâhidlerle ilgili fakat kaybolmuş müstakil bir eser telif ettiği görüşü mevcuttur ${ }^{130}$. Ancak bu görüşün ne denli doğru olduğu şüphelidir.

Muhammed Ebu Zehra: 'Eş'arî haber-i vâhidlerin akaid konularında delil olabileceği görüşüne sahiptir ${ }^{131}$, demektedir. Ancak bu bir yorumdur. Geçerlilik payının ne derece olduğu şüphelidir. Çünkü Eş'arî’nin metodunu devam ettiren kelâmcıların hiç birinin bu fikri savunduğu görülmez. Kelâmcıların sem'iyyât konularını, sırat haktır.., kabir azabı haktır...vb. cümlelerle eserlerinde incelemeleri, onların haber-i vâhidi akâid konularında delil olarak aldıklarını göstermez.

Rey kadısı olan hocası Muhammed b. Mukâtil er-Râzi yolu ile silsilesi Ebu Hanife (v.15o/767)'ye ulaşan, dolayısıyla Ebu Hanife sisteminin bütün özelliklerini bilen ${ }^{132}$ ve bu yoldaki gayretleri sonucu 'Hanefi mezhebinin mütekellimi' olarak vasıflandırılan imam Matûridî ${ }^{133}$ (v.333/944)'nin de haber-i vâhid hakkında, ilim ifade edip etmeyeceğine dair açık bir ifadesine rastlanmamıştır. Ancak bu konudaki değerlendirmesi aynen alınmıştır:

'Diğer bir haber vardır ki (haber-i vâhid), ilim ifade etme ve Hz. Peygamber (s.a.)'den gelmiş bir gerçek olduğuna şehadet etme hususunda tevatür mertebesine ulaşmamış olabilir. Bu haberle amel etmek gerekmektedir. Bu noktada içtihadı terk etmek ve haber-i vâhidi rivayet eden ravilerin durumunu incelemek gereklidir. Bunun neticesinde, nakledilen rivayetin durumu ve olabilirliği ortaya konur. Sonra galip ihtimal ile (zan) amel olunur. Burada yanılmak mümkündür. Çünkü bazen bilgi edinme yollarının en üstünü kabul edilen duyularda bile, ihtimal ile amel edilmektedir. Bunun nedeni, duyuların zayıflığg yanında, idrak edilecek hususun uzaklığı ve inceliğidir. Şu kadar var ki, haber-i vâhid ile amel etmeyi terk etmek, son tahlilde bizi bir neticeye götürmez. Bu noktada amel etmeye veya terk etmeye meyletmek aslında haberin hakkını eda etmemeye götürür. $\mathrm{Bu}$ nedenle, râvilerin durumlarını incelemek ve haber-i vâhidi kat'î delil ile mukayese etmek mecburiyeti vardir ${ }^{134}$.

Matûridî’nin bu sözlerinden, haber-i vâhid ile amel etmenin gerekli olduğunu, fakat akâid konularında bu haberlerin ne tamamen terk edilebileceğini, ne de aynen alınabileceğini, ancak katî delil ile mukayese ettikten ve râvilerin durumu araştırıldıktan sonra kullanılabileceğini anlamak mümkündür.

\footnotetext{
${ }^{130}$ Ali Osman Koçkuzu, Islâm Dininde Haber-i Vâhid'in Itikâdî ve Teşri’̂̀ Yönlerden Yeri ve Değeri, s.64

${ }^{131}$ Muhammed Ebû Zehrâ, İbn Hazm, s.136

${ }^{132}$ Fethullah Huleyf, Kitâbu't-Tevhîd, Mukaddime, 4-5m.

${ }^{133}$ M. Saim Yeprem, Irâde Hürriyeti ve Imâm Mâturîdî, s. 257

134 el-Mâturîdî, Kitâbu’t-Tevhîd, s.9
} 
Eş'arî kelâmını, İmam Eş'arî’den sonra sistematize ederek hararetle müdafaa ve neşredenlerin başında el-Kâdî Ebû Bekr el-Bâkıllânî(v.403/1013) gelmektedir. Ona göre haber-i vâhidler mütevâtir haberler gibi zarûrî ilim ifade etmezler.

'Şayet haber-i vâhid zarûrî ilim ifade etseydi, Peygamber(a.s.)'in naklettiği haberler üzerinde istidlâlle emrolunmazdık' ${ }^{135}$ diyen Bâkıllânî bu sözleriyle, daha ileride görüleceği gibi haber-i vâhidlerin istidlâlî ilim ifade edeceğini anlatmak istemiş olabilir. Çünkü ifadesinden haber-i vâhidin ilim ifade ettiği anlaşılmaktadır. Bu ilim kendi ifadesiyle zarûrî olamayacağına göre, geriye kalan ihtimal bu nevi haberlerin istidlâlî ilim ifade edeceğidir.

Mütekaddimîn kelâmcılarının sonuncusu olarak kabul edilen İmamu'l-Haremeyn Ebu'1-Meâlî el-Cüveynî(v.478/1085)'nin bu konudaki ifadesi daha belirgindir. Ona göre tevâtür derecesine ulaşmayan haber-i vâhid başlı başına ilim ifade etmez. Ancak bir karine ile desteklendiğinde ilim ifade edebilir ki bu karine, haberin ya bir mucize ile teyit olunması veya aklî bir delil ile tasdik olunmasıdır ${ }^{136}$.

Cüveynî ayrıca, imamet konusunu ele aldığı Glyâsi'l-Ümem fi't-Tayâsi'z-Zulem adlı eserinde, Şîa'nın Hz. Ali'nin imameti hakkında ileri sürdüğü hatta bir kısmının Ehl-i Sünnet tarafından da kabul edilen hadislerin değerlendirmesini yapar. Bu hadislerin tevile müsait olmalarının yanı sıra, gerek adetlerinin tevatür derecesine ulaşmamasından ve gerekse râvilerinin güvenilir de olsa yanılabilme ihtimalinin, mevcut olmasından dolayı, zan ifade edip kesin ilim ifade etmeyeceğini anlatır ${ }^{137}$.

Müteahhırîn ilm-i kelâmının kurucusu kabul edilen Ebû Hamîd Muhammed elGazzâlî(v.505/1111), mucizelerin Hz. Peygamber (s.a.)'in sıdkına delil olduğu görüşüne sahiptir. Mucizelerin, haber-i vâhidlerle sabit olduğu için tevatür seviyesine ulaşmadığ ve bu konuda delil olamayacağına dair bir itirazın kendisine yöneltilmesi halinde cevabının şöyle olacağını söyler:

"Her ne kadar bu olaylar haber-i vâhidler ile sabit olmuşsa da, bu haberlerin toplamı bir nevi tevatür derecesine ulaşmıştır. Bu noktada hiç bir Müslüman şüphe etmez. Daha önce haber-i resûl konusu işlenirken görüldüğü gibi, mucize Peygamber(a.s.)'in sıdkına delildir. Peygamber(a.s.)'in mucize izharından sonra naklettiği haber (Kur'an) kesin ilim ifade eder. Peygamber (s.a.)'den Kur'an'ın bize nakledilişi ise mütevâtirdir. Ancak Peygamber(a.s.)'in hissî mucizelerinin her biri haber-i vâhid ile sabit olmuştur. Dolayısıyla bu mucizelerin Peygamber (a.s.)'in sıdkına delil teşkil edip etmeyeceği tartışma konusu yapılabilir. Manevî mütevâtirler, lafzî mütevâtirler gibi her yönüyle ilim ifade etmezler. Ancak bir hadd-i müşterekte ilim ifade ederler. Müşterek hadden kasıt, rivayetlerin hepsinin ortak olduğu noktadır. Bu noktada manevî mütevâtirler kesin ilim

\footnotetext{
135 el-Bâkıllânî, Kitâbu't- Temhîd, s.384

136 el-Cüveynî, el-İrşâd ilâ Kavâtıı'1-Edille fì Usûli'l-İ'tikâd, s.416 vd.

137 el-Cüveynî, Glyâsi'1-Ümem fi't-Tayâsi'z-Zulem, s.36 vd.
} 
ifade ederler. Mucizelerin her biri delâlet açısından zan ifade eder. Fakat hepsinin birleştiği nokta, bu harika hallerin mutlak anlamda mevcut olduğudur. Yani Peygamber (a.s.)'in kesin şekilde mucize gösterdiğidir ${ }^{138}$ ".

Bu açıklamalarından sonra Gazzâlî’ye göre manevî mütevâtir derecesine ulaşan haber-i vâhidlerin kesin ilim ifade ettiği söylenebilir.

Bâkıllânî’nin Eş'arî mezhebinde yaptığı gibi, Matûrîdî mezhebini sistematize eden Ebu'1-Muîn en Nesefî(v.508/1115) ${ }^{139}$, Tabsıretu'l-Edille adlı eserinin son kısımlarına doğru kabir azabı konusunu işlerken, bu konuya dair hadislerin bir değerlendirmesini yapar. Her ne kadar haber-i vâhid sınırları içinde olsa da şöhret derecesine ulaşan haberlerin istidlâlî ilim ifade edeceğini, bundan dolayı kabir azabının kabul edilmesinin gerekli olduğunu anlatır ${ }^{140}$. Nesefî’nin Bahru'l-Kelâm adlı eserinde de aynı düşünceye rastlanır $^{141}$.

Ebû Muhammed Ahmed b. Mahmûd Nûreddin es-Sâbûnî(v.580/1184)'ye göre haber-i vâhidler, mütevâtir haberler gibi ilim ifade etmezler. Bu nevi haberlerin ilim ifade edebilmesi için ya bir karine ile desteklenmesi veya aklî bir delil ile teyit olması gerekir ${ }^{142}$.

Seyfuddîn Âmidî(v.631/1233)'ye göre ise, adil râvi tarafından rivayet edilen haber-i vâhid hakkında ihtilâf söz konusudur ve bu ihtilâfın üç grupta toplanması mümkündür.

Birinci grupta yer alanlar haber-i vâhidin ancak zan anlamında ilim ifade ettiğini savunanlardır. İkinci grupta hadis âlimleri yer alır. Fakat hadisçiler bu konuda iki kısma ayrılırlar. Bir kısmı haber-i vâhidlerin bazılarının ilim ifade edeceğini savunurken, diğer kısmı haber-i vâhidlerin ancak bir karine ile desteklendiği zaman ilim ifade edeceğini savunur. Son grupta yer alan diğer âlimlere göre ise bu nevi haberler ilim ifade etmezler ${ }^{143}$.

Âmidî’ye göre haber-i vâhid kendi başına muteber değildir ve kat'iyyet ifade etmez $^{144}$. Şayet ilim ifade etseydi bu nevi haberleri rivayet eden râvilerde, mütevâtir haberlerde olduğu gibi adalet ve İslâm olma şartının aranmaması gerekirdi ${ }^{145}$.

Âmidî'nin tercih ettiği görüş, haber-i vâhidin karinelerle desteklendiği zaman ilim ifade edeceğidir. Amidî'ye göre, her ne kadar Allah'ın insanlarda, karinesiz olarak haber-i

\footnotetext{
138 el-Gazzâlî, el-íktisâd fi'l-İ'tikâd, s.208 vd.

${ }^{139}$ M. Saim Yeprem, Irâde Hürriyeti ve İmâm Mâturîdî, s.257

140 en-Nesefî, Tebsiretu'1-Edille, vr.277b.

141 en-Nesefî, Bahru'l-Kelâm fì Akâid-i Ehli'l-İslâm, s.42

142 es-Sâbûnî, el-Kifâye fi'l-Hidâye vr.4b.

143 el-Âmidî, el-İhkâm fi Usûli'1-Ahkâm, II/32

144 el-Âmidî, Gâyetü'1-Merâm fi İlmi'1-Kelâm, s.368

145 el-Âmidî, a.g.e, II/33
} 
vâhid ile ilim meydana getirmesi gibi böyle bir şeyin olması mümkünse de normal hallerde bu mümkün değildir ${ }^{146}$.

Bu konuda görüşlerine yer verilecek diğer bir kelâmcı da,

Diğer taraftan Şerhu'l-Akâid yazarı Sâdeddin et-Teftâzânî (v.793/1390), haber-i vâhidlerin ilim ifade etmeyeceklerini, çünkü bu çeşit haberlerin Peygamber (s.a.)'e ait olması hususunda bir takım şüphelerin bulunduğunu anlatır ${ }^{147}$.

Teftâzânı̂’ye göre haber-i vâhid, fıkıh usulünde anlatılan şartların ${ }^{148}$ hepsini üzerinde toplaması halinde bile yalnızca zan ifade eder. İtikâdî konularda ise zanna itibar edilmez. Özellikle haber, Kur'an'ın zahirine ters düşerse o zaman haber-i vâhide hiç itibar edilmez ${ }^{149}$.

Kelâmcılar haber-i vâhid ile amel etme konusunda fikir birliği halindedir. Ancak itikâdî konular ilim ifade eden yol ve vasıtalarla bilineceğinden bu konularda haber-i vâhidi delil olarak kabul etmezler. Fakat karinelerle desteklenmiş haber-i vâhidin ilim ifade edeceğini söylemeleri ve bu nedenle çoğu haber-i vâhidlerle sabit olan sem'iyyât konularını kabul etmeleri kelâmcılara bu konuda yapılan tenkitlerin çoğunun haksız olduğunu ortaya çıkarmaktadır. Yani onların kendilerine ulaşan haberleri istedikleri gibi tevil edip, fikirlerine uyanları alıp fikirlerine uymayanları kabul etmemeleri ve taşıdıkları akide ile ilgili olarak mervî haberlere itimat etmediklerinin ${ }^{150}$ doğruluk derecesi görüldüğü gibi tartışma konusudur.

\section{Yeni İlm-i Kelâm Devri}

Yeni İlm-i Kelâm devri temsilcileri ilmi geleneğin yaygın görüşünü devam ettirmişlerdir. Nitekim haber-i vâhid konusunda daha önce geçen görüşleri, hemen hemen hiç değişiklik olmaksızın yeni devir kelâmcılarında da görmek mümkündür. Örneğin Muhammed Abduh(v.1323/1905), konu ile ilgili olarak Risâletu't-Tevhîd adlı eserinde şunları anlatır:

"Haber-i vahidi işiten ve bu haberin rivayetinin sahih olduğunu kabul eden kimseye bu habere iman etmek vaciptir. Fakat kendisine haber ulaşmamış veya ulaşan haberin sıhhatinde bir şüphe arız olmuşsa ve bu haber mütevâtir değilse böyle bir haberi tasdik etmeyen kimse iman noktasından ta'n edilemez ${ }^{151 \text { ", }}$

Abduh'un bu sözlerinden, itikâdî konularda haber-i vâhidin delil olamayacağını anlamak mümkün olduğu gibi, ilk cümlesinde geçen “...iman etmek vaciptir” sözünden de,

\footnotetext{
146 el-Âmidî, a.g.e, II/32

147 et-Teftâzânî, Şerhu'l-Akâîd, s.40

${ }^{148}$ Adalet, akıl, islâm, zabt, isnâd, ref'.

149 et-Teftâzânî, Şerhu'l-Akâî, s.169

${ }^{150}$ Talât Koçyiğit, Hadiscilerle Kelâmcılar Arasındaki Münakaşalar, s.248

${ }^{151}$ Muhammed Abduh, Risâletu't-Tevhîd, s.154
} 
delil olabileceği anlaşılabilir. Bu değerlendirmesinden kesin bir sonuca ulaşmak mümkün görünmemektedir.

Ancak Abduh'un fikirlerini yayan talebesi Reşid Rıza(v.1354/1935)'nın bu konudaki açık ifadesinin, meseleyi Abduh açısından da aydınlığa kavuşturduğu düşünülebilir.

Reşid Rıza, içtihat konularının üzerine ikame edilecek şer'i delillerin, sübûtu kat'î olan Kur'an veya mütevâtir haberlerin olması gerektiğini, zira haber-i vâhidlerin her ne kadar sahih olsa bile delâletinin zannî olacağını, itikâdî konularda ise zanna itibar edilemeyeceğini söylemektedir ${ }^{152}$.

Buna karşın Abdüllâtif Harpûtî Tenkihu'l-Kelâm adlı eserinde sem'iyyât konularını incelerken, bunların mümkün olduğunu ve Peygamber (s.a.)'den nakledildiğine dikkati çeker. Ona göre, bu konular haber-i vâhidlerle sabit olmuştur. Bu türden haberlerin dinde şöhret derecesine ulaşmasından dolayı kendilerine inanmanın gerekli olduğunu, inanmayanların bid' at ve delâletle itham edileceğini anlatır ${ }^{153}$.

Sırrı Giridî’nin konu ile ilgili görüşü nettir. Nakdu'l-Kelâm adlı eserinde, mütevâtir mertebesine ulaşmayan haber-i vahidin fıkıh usulündeki şartların hepsini üzerinde taşıması halinde bile zan ifade edeceğini, kendisiyle amelin gerekli olduğunu, fakat itikâdî konularda zanna itibar edilmediğinden delil olamayacağını anlatmaktadır ${ }^{154}$.

Yeni İlm-i Kelâm devrinin mevfur eserler bırakan kelâmcısı İzmirli İsmail Hakk1 (1869/1946) da itikâdî konularda Kur'an ve mütevâtir haberlerin delil teşkil edeceğini söyler. İzmirli'ye göre haber-i vâhidler, iman ve delâlette ölçü olmayıp, sadece amelde ve ahlâkta delil teşkil ederler. Haber-i vâhidler şartları tekemmül ettiğinde dahi zan ifade ederler. Akâid nazarında zan muteber olmadığından bu tür haberler kelâm ilminde kesin delil olamazlar. Ancak kendileriyle amel etmek vaciptir ${ }^{155}$.

Yine bu devrin temsilcilerinden Ömer Nasuhi Bilmen ve Ali Arslan Aydın da konu hakkındaki fikirlerini hemen hemen aynı ifadelerle anlatmaktadırlar. ${ }^{156}$

Yeni İlm-i Kelâm Devri temsilcileri görüldüğü gibi haber-i vâhidi amelî konularda delil olarak kabul etmişlerdir. İtikâdî konularda kelâmcılar zanna itibar etmezler. Haber-i vâhidin zan ifade etmesi, haberin Peygamber (s.a.)'e ait olması hususunda bazı şüphelerin bulunmasından dolayıdır. Ancak şöhret derecesine ulaşan haber-i vâhidin istidlâlî ilim ifade edeceğini de kabul etmişlerdir.

\footnotetext{
${ }^{152}$ Reşid Rıza, Mezâhibin Telfíki ve İslâm'ın Bir Noktaya Cem'i, s.45 vd.

${ }^{153}$ Abdüllâtif Harpûtî, Tenkîhu'1-Kelâm fì Akâid-i Ehli'l-İslâm, s.424 vd.

${ }^{154}$ Sırrı Giridî, Nakdu'l-Kelâm fi Akâidi'1-İslâm, s.24vd.

155 İzmirli İsmail Hakkı, Yeni İlm-i Kelâm, s. 17 ve 34

${ }^{156}$ Ömer Nasuhi Bilmen, Muvazzah İlm-i Kelâm, s.35; Ali Arslan Aydın, İslâm İnançları ve Felsefesi, s.95
} 


\section{Sonuç}

İlim kelimesi Kelâm ilminde, bilgi kelimesini karşılamak için kullanılmıştır. Bilgi ise üç yoldan, beş duyu, akıl ve haber-i sâdık vasıtası ile elde edilmektedir.

Duyular ile elde edilen bilgilerin kesin bilgi olduğu, bu tür bilgilerin delil ve istidlâle muhtaç olmadığı dolayısıyla kendilerinde şüphe ve tereddüt bulunmayacağ âlimlerce ittifakla kabul edilmiştir.

Yine akıl ile elde edilen bilgilerin de beş duyu ile elde edilen bilgiler gibi zarurî olduğu ve bu bilgilerde şüphe bulunmayacağı ittifakla kabul edilmiştir.

Mütevâtir haberlerin de yakinî ilim gerektirdiği ve bu tür haberlerden şüphe edilemeyeceği konusunda da Ehl-i Sünnet âlimleri ittifak halindedirler.

Mütevâtir mertebesine ulaşmayan haber-i vâhidin ilim ifade etmesi hususunda ise ihtilâf mevcuttur. Bu konuda fikir yürüten İslâm âlimleri Selefiyye ve Kelâmcılar olmak üzere iki büyük grup içinde yer almışlardır.

Selefiyye bütünlüğü içinde, haber-i vâhidin değeri konusunda iki ayrı görüş hâkimdir. Selefiyye'nin bir kısmı haber-i vâhidin kesin ilim ifade edeceğini savunarak haber-i vâhidi amelî konularda olduğu gibi, itikâdî konularda da delil olarak kabul etmişler ve bu hususta haberler arasında mütevâtir ve âhad ayırımında bulunmamışlardır. Bu grup, haberin sahih şekilde Hz. Peygamber (a.s.)'den güvenilir yollar ve râviler tarafından ulaşmasını esas almışlardır.

Selefiyye'nin diğer kısmı ise haber-i vâhidin başlı başına ilim ifade etmeyeceği fikrini savunmuşlardır. Bu tür haberleri amelî konularda esas almışlar, fakat itikâdî konularda delil olarak kabul etmemişlerdir. Bunun nedeni, haber-i vahidin Hz. Peygamber (a.s.)'e ulaştığına kesin bir kanaat getirememelerinden kaynaklanmaktadır.

Ehl-i Sünnet kelâmcıları haber-i vâhid ile amel etme hususunda fikir birliği halindedir. Ancak kelâmcılara göre itikâdî konular sadece ilim ifade eden yol ve vasıtalarla bilinir. Bundan dolayı kelâmcılar, itikâdî konularda haber-i vâhidi delil olarak kabul etmezler. Haber-i vahide itibar etmemeleri, bu nevi haberlerin zan ifade etmesinden dolayıdır. Haber-i vâhidin zan ifade etmesinin nedeni ise haberin Hz. Peygamber (a.s.)'e ait olması hususunda bazı şüphelerin bulunmasından dolayıdır.

Kelâmcılar şöhret derecesine ulaşan haber-i vâhidlerin istidlâlî ilim ifade edeceği fikrini savunmuşlar, buna bağlı olarak da birçoğu haber-i vâhidle sabit olan sem'iyyât konularını kabul etmişlerdir.

Kelâmcılar ve Selefiyye, haber-i vâhidlerle amel etmenin gerekli olduğu ve karinelerle desteklenmiş haber-i vâhidin ilim ifade edeceği hususunda ise birleşmişlerdir. 


\section{Kaynakça}

Abduh, Muhammed. (1387) Risâletü’t-Tevhîd, Misır.

Abdulbâkî, Muhammed Fuâd. (1984) el-Mu'cemu'l-Müfehres li Elf'âzi'l-Kur'âni'l-Kerîm, İstanbul.

Ahmed Emîn. Fecru'1-İslâm, (1976) trc. Ahmet Serdaroğlu, Ankara.

el-Âmidî, Seyfuddîn Ebu'1-Hasan Ali b. Muhammed. (1391) Gayetü'1-Merâm fì İlmi'1-Kelâm, Kahire.

el-Âmidî, Seyfuddîn Ebu'l-Hasan Ali b. Muhammed. (1387) el-İhkâm fî Usûli'l-Ahkâm, C. IIV, Kahire.

Aydın, Ali Arslan. (1973) İslâm İnançları ve Felsefesi, Ankara.

el-Bağdâdî, Ebû Bekr Anmed b. Ali b. Sâbit. (ts.) el-Kifâye fî̀ Ilmi'r-Rivâye, Medine-i Münevvere.

el-Bâkıllânî, Ebû Bekr Muhammed b. et-Tayyib. (1957) Kitâbu't- Temhîd, nşr. Richard J. Mc. Charty, Beyrut.

el-Buhârî, Ebû Abdillâh Muhammed b. İsmail. (1979) el-Câmiu's-Sahîh, C. I-VIII, İstanbul.

el-Buhârî, Abdülazîz b. Ahmed. (1307) Keşfu'l-Esrâr Şerhu Usûli’1-Pezdevî, C. I-IV, İstanbul.

Bilmen, Ömer Nasuhi. (1972) Muvazzah İlm-i Kelâm, İstanbul.

el-Cürcânî, es-Seyyîd eş-Şerîf, Ali b. Muhammed. (1321) Şerhu'l-Mevâkıf, C. I-II, İstanbul.

el-Cürcânî, es-Seyyîd eş-Şerîf, Ali b. Muhammed. (1308) et-Ta'rîfât, İstanbul.

el-Cüveynî, İmâmu'1-Haremeyn Abdülmelik b. Abdullah, el-Giyâsî. (1401) Gıyâsü'1-Ümem fi't-Tiyâsi'z-Zulem, Katar.

el-Cüveynî, İmâmu'1-Haremeyn Abdülmelik b. Abdullah, el-Giyâsî. (1369) el-İrşâd ilâ Kavâtıı'1-Edille fî Usûli'l-İ'tikâd, nşr. M. Yusuf Mûsa, Abdulmun'im Abdülhamîd, Misır.

el-Cüveynî, İmâmu'1-Haremeyn Abdülmelik b. Abdullah, el-Giyâsî. (1969) eş-Şâmil fî Usûli'd-Dîn, nşr, Alî Sâmi en-Neşşâr ve arkadaşları, İskenderiye.

Ebû Zehrâ, Muhammed. (1367) Ahmed b.Hanbel, Kahire.

Ebû Zehrâ, Muhammed. (ts.) İbn Hazm, Kahire.

Ebû Zehrâ, Muhammed. (1367) eş-Şâfî̀, Kahire.

Ebû Zehrâ, Muhammed. (1958) İbn Teymiyye, Kahire.

el-Gazzâlî, Ebû Hâmid Muhammed b. Muhammed. (1962) el-İktisâd fi'l-İ'tikâd, nşr. İbrahim Agâh Çubukçu ve Hüseyin Atay, Ankara. 
el-Gazzâlî, Ebû Hâmid Muhammed b. Muhammed. (1979) Mi'yâru’l-İlm, Misır.

Giridî, Sırrı, (1302) Nakdu'1-Kelâm fî Akâidi'1-İslâm, İstanbul.

el-Harpûtî, Abdullâtîf. (1330) Tekmile-i Tenkîhu'1-Kelâm, İstanbul.

el-Harpûtî, Abdullâtîf. (1330) Tenkîhu'1-Kelâm fî Akâid-i Ehli'l-İslâm, İstanbul.

Huleyf, Fethullâh. (1979) Kitâbu’t-Tevhîd, Mukaddime, İstanbul.

el-Isfahânî, Ebu'l-Kâsım el-Huseyn b. Muhammed, er-Râğıb. (1970) el-Müfredât fi Garîbi'1Kur'ân, Misır.

İbn Ebî Ya'lâ, el-Kâdî Ebu'1-Huseyn, Muhammed. (ts.) Tabâkâtu'1-Hanâbile, C. I-II, Beyrut. İbn Hazm, Ebû Muhammed Ali b. Ahmed. (ts.) el-İhkâm fi Usûli'l-Ahkâm, C. I-IV, Kahire.

İbnu'1-Kayyim, Şemsüddîn Ebû Abdillâh Muhammed b. Ebî Bekr, el-Cevziyye. (1374) I'lâmu'l-Muvakkı̂̂n an Rabbi'l-Âlemîn, C. I-IV, Misır.

İbnu'1-Manzûr, Ebû'1-Fadl Muhammed b. Mükrim el-Efrîkî. (ts.) Lisânu'1-Arab, C. I-IV, Beyrut.

İbn Teymiyye, Ahmed b. Abdülhalîm. (1340) Risâle-i Ref'ül-Melâm, ani'l-Eimmeti'1-A'lâm, Misir.

İzmirli, İsmail Hakkı. (1981) Yeni İlm-i Kelâm, Ankara.

Karaman, Hayreddin. (ts.) İslâm Hukukunda İctihad, Ankara.

el-Kettânî, Ebû Abdillâh Muhammed b. Ebi'1-Feyd, Câfer. (1328) Nâzmu'1-Mütenâsir fi'1Hadîsi'1-Mütevâtir, Halep.

Koçkuzu, Ali Osman; Kandemir, M. Yaşar. (1971-1972) Hadis Ders Notları, 4.Sınıf, Konya Yüksek İslâm Enstitüsü, Konya.

Koçkuzu, Ali Osman. (1968) 'İslâm Dininde Haber-i Vâhid'in İtikâdî ve Teşrî̂ Yönlerden Yeri ve Değeri', Konya.

Koçyiğit, Talât. (1969) Hadiscilerle Kelâmcılar Arasındaki Münakaşalar, Ankara.

Koçyiğit, Talât. (1967) 'Âhad Haberlerin Değeri’, İlahiyat Fakültesi Dergisi, C. XIV, Ankara.

el-Mâturîdî, Ebû Mansûr Muhammed b. Muhammed b. Mahmûd. (1979) Kitâbu't-Tevhîd, nşr. Fethullâh Huleyf, İstanbul.

en-Nesefî̀, Meymûn b. Muhammed, Ebu'1-Muîn. (1329) Bahru'l-Kelâm fî Akâid-i Ehli'1İslâm, Konya.

en-Nesefî, Meymûn b. Muhammed, Ebu'1-Muîn. Tebsıretu'l-Edille, Süleymaniye (Cârullâh. Efendi) Ktp. nr. 1128

en-Nevevî. (1388) et-Takrîb, Misır. 
Öner, Necati. (1982) Klâsik Mantık, Ankara.

er-Râzî, Ebû Abdillâh Muhammed b. Ömer. (ts.) Mefâtîhu'l-Gayb, C. I-XXXII, Tahran.

er-Râzî, Ebû Abdillâh Muhammed b. Ömer. (1978) el-Muhassal, (trc. Hüseyin Atay), Ankara.

Rızâ, Reşîd, Muhammed el-Hüseynî. (1332) Mezâhibin Telfỉki ve İslâm'ın Bir Noktaya Cem'i, (trc. Ahmed Hamdi Akseki), İstanbul.

es-Sâbûnî, Ebû Muhammed Ahmed b.Mahmûd, Nûreddîn. (1979) el-Bidâye fî̀ Usûli'd-Dîn, nşr. Bekir Topaloğlu, Ankara.

es-Sâbûnî, Ebû Muhammed Ahmed b.Mahmûd, Nûreddîn. el-Kifâye fi'l-Hidâye, Lâleli Ktp. nr. 2271

es-Sâlih, Subhî. (1385) Ulûmu'1-Hadîs, Beyrut.

es-Suyûtî, Ebû Bekr Abdurrahmân b. Ebî Bekr, Celâleddin. (1379) Tebrîbu'r-Râvî Şerhu Takribi'n-Nevevî, Medine-i Münevvere.

eş-Şâfiî, Muhammed b. İdrîs. (1399) er-Risâle, nşr. Ahmed Muhammed Şâkir, Kahire.

eş-Şehristânî, Ebu'l-Feth Muhammed b. Abdulkerîm. (1395) el-Milel ve'n Nihâl, C. I-II, Beyrut.

et-Teftâzânî, Mes'ûd b.Ömer, Sa'düddîn. (1973) Şerhu'1-Akâid, İstanbul.

et-Tehânevî, Muhammed A'lâ b.Ali, İbnu'1-Kâdî. (1862) Keşşâfu Istılâhâti'l-Funûn, C. I-II, Kalküta.

Topaloğlu, Bekir. (1981) Kelâm İlmi Giriş, İstanbul.

Yeprem, M.Saim. (1980) Irâde Hürriyeti ve İmâm Mâtürîdî̀, İstanbul. 